\title{
Siyasal ve Sosyal Bağlamda Mankurt Kavramının Türk Yazılı Basınında Metaforik Kullanımı ${ }^{1}$
}

\author{
Dursun YILMAZ ${ }^{2}$ ve Murat SEZGIN ${ }^{3}$
}

Öz

Türk Dil Kurumu sözlüğünde “ulusal kimlikten uzaklaşan, içinde bulunduğu topluma yabancılaşan” şeklinde tanımlanan Mankurt sözcüğ̈ ilk olarak Kırgız yazar Cengiz Aytmatov tarafindan 1980 yılında kaleme alınan Gün Olur Asra Bedel eserindeki Nayman Ana efsanesinde kullanılarak literatüre kazandırılmıştır. Kavram, daha çok sosyal psikoloji alanında kullanılan bir terim olsa da günümüzde sosyolojiden siyasete pek çok konuyu açıklamada kullanılmaktadır. Aytmatov, Gün Olur Asra Bedel (1980) romanını Orta Asya Türk Cumhuriyetlerinin henüz SSCB'nin yönetimi altında olduğu tarihlerde kaleme almıştır. Yazara, bu eseri ile milli şuuru canlandırmayı, özünden kopmamayı ve milli bilinç oluşturmayı amaçladığı yorumları yapılmıştır. Mankurt kavramı, bugüne kadar Türkiye matbuatında kitap, makale ve gazete fikrası gibi pek çok yazında ele alınmıştır. Bu yazınlarda kavramı konu edenler genelde kendi görüşlerine uygun olarak yorumlamış, kendi düşünsel perspektifinden kavramı ele almıştır. Bunun için de birbiriyle çelişen tanımlamalar ve yorumlar ortaya çıkmıştır. Uluslararası Türk Kültürü Teşkilatı TÜRKSOY’un 2018 yılını "Cengiz Aytmatov Yılı" ilan etmesi münasebetiyle hem Aytmatov’u anmak hem de literatüre kazandırdığı Mankurt kavramının Türk kamuoyunda oluşturduğu tutum, kullanıldığı bağlam, Türk ulusal basınında gündem oluşturması ve Cumhurbaşkanı Erdoğan'ın Mankurt ifadesini metaforik olarak kullanması bu çalışmada ele alınmıştır. Çalışma, gündem belirleme kuramı çerçevesinde içerik analizi yöntemi ile yapılmıştır.

Anabtar Kelimeler: Mankurtlaştırma, Cengiz Aytmatov, Türk Basını, Gündem Belirleme, İçerik Analizi.

The Metaphoric Use of the Concept of Mankurt on the Turkish Printed Press in terms of Social and Politics

\begin{abstract}
Mankurt is defined as 'the one who moved away from national identity, became alienated from the society' and used first in the legend of Nayman in "The Day Lasts More than a Hundred Years" written by Chingiz Aitmatov in 1980. Although the concept is used mostly in the field of social-psychology, it is preferred to explain many topics from sociology to politics. 'The Day Lasts More Than a Hundred Years' written during the years when the Cental Asian Turkic Republics were still under the control of the USSR is thought to aim at reviving national conscience and create national consciousness. The concept of Mankurt is handled in many kinds of books, essays and newspaper in Turkey. The people focused on the concept mostly from their own perspectives. This caused contradictory comments and definitions. This study both aims to commemorate Chingiz Aitmatov and focus on the concept of Mankurt and its use in the Turkish public opinion because of the fact that Aksoy announces the year 2018 as Chingiz Aitmatov Year. After the President Erdoğan used the word of Mankurt in the meeting of 'Millions of Breath Band Together against Terror' in İstanbul Yenikap1 in 2015, many people used the concept in definitions and explanations. The study deals with the history of the concept, its origin and reference.
\end{abstract}

Key Words: Mankurtization, Chingiz Aitmatov, Content Analysis

\section{Atıf İçin / Please Cite As:}

Yılmaz, D. ve Sezgin, M. (2020). Siyasal ve sosyal bağlamda mankurt kavramının Türk yazılı basınında metaforik kullanımı. Manas Sosyal Arastırmalar Dergisi, 9(2), 1010-1030.

Geliş Tarihi / Received Date: 05.12.2018

Kabul Tarihi / Accepted Date: 12.02.2020

\footnotetext{
${ }^{1}$ Bu çalş̧ma Türkküm -2018 Uluslararası Türk Kültürü ve Medeniyeti Kongresinde bildiri olarak sunulmuştur.

${ }^{2}$ Dr. Öğrencisi - Uşak Üniversitesi, Sosyal Bilimler Enstitüsü, İletişim Bilimleri Anabilim Dalı, dursun_ylmz@yahoo.com ORCID ID: 0000-0001-6161-3482

${ }^{3}$ Doç. Dr. - Uşak Üniversitesi, İletişim Fakültesi, murat.sezgin@usak.edu.tr

ORCID ID: 0000-0003-2200-3301
} 


\section{Giriş}

\section{Mankurt Kavramının Tarihi Bağlamı ve Metaforik Kullanımı}

Türkiye Cumhuriyeti Cumhurbaşkanı Recep Tayyip Erdoğan'ın 20 Eylül 2015 tarihinde İstanbul Yenikapı'da, "Milyonlarca Nefes, Teröre Karşı Tek Ses" mitinginde kullandığı Mankurt metaforunun tarihçesi yüz ylllar öncesine dayansa da onu tarihin derinliklerinden 1980 yllında kaleme aldığ Gün Olur Asra Bedel/ Kılmmga Tete Bir Kün eseri ile çıarıp günümüzün literatürüne sokan kişi Kırgız yazar Cengiz Aytmatov olmuştur. Aytamatov, eserlerinde Sovyet rejimine ve totaliter sistemlere yönelik eleştirilerini yerel kültürden aldığı mitlerden esinlenerek evrensele taşımış bir yazardır.

Literatüre girdiği günden beri entelektüel camiada zaman zaman tartıșlan ve gündeme gelen Mankurt kavramı 2015 yılında Erdoğan tarafından yüzbinlerce kişinin katıldığı bir mitingde dile getirilmiş, o tarihten sonra bu metafor yaygin kitle iletişim araçlarında yoğun bir şekilde yer almış, medyadaki birçok kalem erbabı da kavramı kullanmaya başlamışır. Kavram bugün Türk kamuoyunun yabancısı olduğu değil, aşinası olduğu bir metafor haline gelmiştir.

Çalışma gündem belirleme kuramı çerçevesinde Mankurt metaforunun Türk yazılı basınında ne şekilde yer aldığ1 ve kavramın kamuoyuna nasıl sunulduğu üzerine yapılmıştır. Araştırmada nitel araştırma desenlerinden olan içerik çözümleme yöntemi kullanılmış, yaygın ulusal gazetelerin birinci sayfa içeriklerinin analizi yapılmıştır.

Mankurt kavramı, Aytmatov'un Aralık 1979-Mart 1980 tarihleri arasında Issık-Köl bölgesinde yer alan Çolpan Ata şehrinde Rusça olarak kaleme aldığı Gün Olur Asra Bedel adlı eseri ile ilk defa literatüre kazandırılmıştır. Eser 1981 yılında Novy Mir (Yeni Dünya) adlı gazete de tefrika edilmiştir. Yazılı basının etkin olduğu bu dönemde gazete beş milyon tirajla basılmaktaydı. Gazetenin bu tirajinda Aytmatov'un haklı şöhretinin de bir karşıllğ̆ olduğu söylenebilir (Kardaş Edebiyatlar der., 23: 1983. Söyleşi: Nioole Zant, çev. Süleyman Büyükdağ). 1983 yllında SSCB Devlet Ödülü'ne de layık görülen Gün Olur Asra Bedel, aynı yıl Fransız edebiyat eleştirmeni Vladimir Lachine tarafından Fransa'da yılın kitabı olarak ilan edilmiştir. Aytmatov'un en hacimli eseri olan Gün Olur Asra Bedelde yazar, dünyayı ilgilendiren pek çok soruna değinmiştir. Başta çevre sorunları (Aral Gölü’nün kurumaya başlaması) olmak üzere değişen ekonomik yap1, makineleşmenin artması, dönemin sosyalist ve kapitalist sistemlerinin insan ihtiyaçlarına karşlık verememesi (yeni bir gezegenin keşfi), ezeli rakip devletlerin (ABD ve SSCB) ortak menfaatler için müttefik olabilecekleri (birlikte uzay çalışmaları yapmaları) gibi konulara da derin göndermeler yapmıştır. Yazarın, romanda geçen Dönenbay kuşu karakteri ile SSCB'ye karşı Türk yurtlarının bağımsızlı̆ını sembolize ettiği de yorumlanmıştır (Kolcu, 1989, s. 2-3). Yazarın Fransa'da verdiği bir mülakatını 1983 y1lında Kardaş Edebiyatlar dergisi sayfalarına taşımıştır. Dergiden iktibasla; muhabir Aytmatov'a "Robot adam Mankurt hakkındaki düşünceleriniz nedir?" diye sormuştur. Aytmatov gazetecinin sorusunu Fransız eleștirmen Lachine'ye atıf yaparak "Kitap Rusya'da yayımlandığından beri görünen o ki Mankurt ortak bir isim oldu ve daha umumi bir isim olan 'Mankurtizasyon' uyduruldu. Eleştirmen Vladimir Lachine, Le Monde'de kavramı; 'düşünce yeteneği olmayan, muhakeme yürütemeyen, benzerlerinin acılarını hissetmeyen ve farklı manevi değerleri kabul etmeyen biri' olarak tanımlamıştır. Yedigey'in cenaze kervanının cetlerinin mezarlığına girmesine müsaade etmeyen bir muhafız teğmendir.' Çağdaş bir Frenkeştayn tarafından biçimlendirilip yapılan zavallı Mankurt hiç de hayali bir tür değildir.” (Kardaş Edebiyatlar, 23: 1983) şeklinde cevap vermiştir.

Mankurt kavramının etimolojisine ve tarihi çıkıs noktasına geçmeden önce yazarın kavramı kendi bağlamında nasıl bir hikâye üzerine kurguladığına değinilmesi yerinde olacaktır. Aytamatov'un ekser eserleri İkinci Dünya Savaşı yıllarının öncesini ve sonrasını anlattı̆̆1 olaylar örgüsü içinde geçer. Bu romanda da cepheden mecburi dönüş yapmış "Yedigey Cangeldin" adlı karakterin asra bedel yaşadığı bir gününü anlatır. Yedigey, cepheden yaralı olarak dönmüş bir askerdir ve eşiyle birlikte tanıştıkları Kazangap'n desteğiyle, senelerdir Boranlı isimli yerleşim bölgesindeki tren istasyonu aktarma merkezinde çalş̧ıyordur. Bir akşam ona çok yardımı dokunan dostu Kazangap'ın ölüm haberini alır. Bunun üzerine dostuna cenaze merasimi düzenler. Yedigey, Dostunun cenazesini Ata-beyit mezarllğına götürürken bu kutsal sayılan mezarlık adeta toplumsal bir hafızayı temsilen ona, geçmiş tüm yaşamını sorgulatır (Tan, 2015: 49). Kendisine ve milletine ait geçmişi bir film şeridi gibi Yedigey’in gözlerinin önünden akar. Aytmatov, Yedigey'in şahsında geçmişle ve yaşadığı dönemle ilişki kurarak zaman içinde yok edilmiş, ya da unutturulmuş dinî ve kültürel değerleri hatırlatmıştır. Yazar, babasının defninde yapılan dini tören ve gelenekleri küçümseyen Kazangap’n oğlu Sabitcan (Kazak) ve Ata-beyit mezarlığına cenazeyi sokmayan, 
ana dilini yabancı dil kabul ederek Rusça konuşan Kızıl Ordu subayı Tansıkbayev (Kırgız) karakterlerinde ise Sovyet rejiminin eğitim sisteminden geçen Kırgız-Kazak gençlerinin geçmişlerine ve kutsallarına karşı nasıl yabancılaştığını, onları nasıl küçümseyip yok saydığını yani Mankurtlaştıklarını betimlemiştir (Ağır, 2013, s. 2). Romanın diğer bir kahramanı ise görevden el çektirilen coğrafya öğretmeni Abutalip Kuttubayev'dir. Usta yazar Abutalip'i ön plana çıarmaz çünkü eserin yayınlandığ1 tarihte SSCB hala hüküm sürmektedir bu nedenle ön plana Yedigey’i çıkararak asıl mesajlarını Abutalip üstünden verdiği söylenebilir. Abutalip, öğretmen olarak çalışırken İkinci Dünya Savaşına katıllmış, esir düşmüş, esaretten kaçarak kurtulmuş, sonra rejim tarafindan casuslukla suçlanarak Boranll’ya sürülmüş aslına, töresine bağll, gelecek nesiller için çırpınan aydın ve arif bir kişidir (Durmaz, 57). Aytmatov'un Mankurt'u tanımladığı Nayman Ana efsanesi de işte bu Abutalip'in Boranlı çocuklarına geçmişlerini, törelerini unutmasınlar diye anlattığı ve gaz lambası ışı̆̆ında eliyle kayda geçirdiği bir anlatıdır. Romandaki Abutalip, Sovyet rejimine kurban edilen Kazak, Kırgız, Özbek ve Türkmen gibi Türk aydınlarının bir temsilidir. Aytmatov'un roman kahramanı Abutalip'te tıpkı kendi babası ve diğer Orta Asya aydınları gibi SSCB rejimi tarafindan suçsuz yere öldürülmüştür.

Romanda geçen Nayman Ana efsanesi Manas destanında geçtiği için Kırgızlarca ve diğer Orta Asya halklarınca çok bilinen trajik bir öyküdür. Öykü özet şekliyle şöyledir: Juan-juanlar ${ }^{4}$ düşmanlarına çok canice işkenceler yapan barbar bir toplumdur. Kırgızlarla Juan-juanlar sürekli savaşan komşu milletlerdir. Savaşlarda Juan-juanlar kazandığı zaman esir ettikleri tutsakların zayıf olanlarını köle olarak satar, güçlü olanlarını ise çöle götürüp, bir kuyu açar ve burada boğazına kadar toprağa gömerlermiş. Kaynaklarda esirin başını çarparak ölmemesi için el ve ayaklarını çarmı misal bağladıkları da yazılmaktadır. Esirlerin saçlarını kazıyarak, taze bir deve veya dana derisini kazınmış başa iyice sararlar ve günlerce (5 gün) güneş altında bırakırlar. Deri kurudukça başı daha sıkı kavrar, bu durum beyne doğrudan zarar vermekle birlikte yeniden çıkmaya başlayan saçların da deve derisini delemeyerek geri dönüp kafaya batması esirlere korkunç bir acı verirmiş. Bu işkenceden sağ çıkabilenler bütün geçmişlerini unutup, hafızalarında geçmişe ait en ufak bir hatıra kırıntısı bile kalmazmış. Robottan farklı olarak sadece fizyolojik ihtiyaçlarını yerine getirebilen, duygusuz, kendi efendilerinin emirlerini yerine getiren iradesiz ve kişiliksiz bir Mankurt olurmuş.

Gün Olur Asra Bedel'de Juan-juanlar tarafindan Kırgızların Nayman kabilesinden esir olarak kaçırılan Nayman Ana'nın oğlu Colaman'ın yukarıda anlatılan işkence yöntemleri ile nasıl Mankurt'a dönüştürüldüğü anlatılmıştır. Nayman Ana'nın Coloman'ı uzun arayışlar sonucu bulması ve analık şefkatiyle yaklaşarak ona geçmişini hatırlatmak isteme çabalarına karşılık, geçmişine yönelik hiçbir şey hatırlamayan Coloman'ın efendisi Juan-juanların talimatıyla anasını bir okla kalbinden vurarak öldürmesi betimlenmiştir.

\section{Yöntem}

\section{İçerik Analizi}

İçerik analizi yöntemi çıkışı itibariyle gazete haberlerinin analiz edilmesi temeline dayanmaktadır. Bu çalş̧ma da iletişim bilimlerinin kapsamında olduğu için içerik analizi yöntemi ile görünen içeriğin anlamı üzerine pozitivist yaklaşım temel alınmıştır. Yöntem hakkında tanımlamaları bulunan kuramcılar Berelson, Stone, Berger, Duvarger, Cartwright ve Fox yöntemin ortak özelliklerini; içeriğin açık, nesnel ve sistematik şekilde ölçülebilen, sınıflandırılan, özetlenen ve içerikten sonuçlar çıkarılan bir yöntem olduğuna ittifak etmişlerdir. Görünen nesnelerden görünmeyen sonuçların çıkarılması, söylenenlerden söylenmeyenlerin tespit edilebilmesine yönelik bir yöntem olduğunu ileri sürenlerde vardır. İçerik analizine nicel veri oluşturma ve betimleme de denilmektedir (Tavşancil-Aslan, 2001, s. 21-22). Aziz (1994), bahsi geçen kuramciların ifadelerinden nesnellik, yansızlık, sistematiklik, yinelenebilirlik ve tekrar uygulanabilirlik şeklinde ortak bir tanımlama çıkarmışır.

Bu çalısmada Mankurt metaforunun gazetelerin vitrin sayfası olarak kabul edilen birinci sayfalarında nasıl sunulduğu sistematik şekilde ele alınarak hangi bağlamda ve şekilde kullanıldığ1 tespit edilmeye çalısılmıştır. Çalışma yaygın ulusal gazetelerin birinci sayfaları ile sınırlandırılmıştır. Basının gündem oluştururken hangi konuları daha önemli gördüğü, gündemlerine neyi taşıdıkları da Mankurt metaforu üzerinden değerlendirilmiştir. Bu bağlamda, 2015 Eylül ayı ile 2018 Eylül ayı içerisinde yayın yapmış bugün

4 “...Juan-juanların Moğol menşeli olabileceği tezi geniş bir kesim tarafından kabul edilmiştir. Juan-juanların sonraları Avrupa sahasında ortaya çıkan Avarların selefi olabileceğini öne süren görüşler dillendirilse de bu eşleştirmenin en zayıf tarafı umumiyetle Avarların Türk ve Juan-juanların Moğol menşeli olarak kabul edilmesi ve etnik menşelerinin belirsiz olduğu fikrinin mevcudiyetidir (Yildırım, 2015, s. 54)". 
ise yayından kalkmış veya kaldırılmış bütün gazetelerin birinci sayfalarında Mankurt metaforu ile ilgili olarak yayınlanan her türlü haberin içerik analizi yapılmıştır. Mankurt kavramı yukarıda da ifade edildiği üzere Aytmatov'un Gün Olur Asra Bedel adlı eserinin yayınlanmasiyla seksenli ylllarda kamuoyu gündemine gelmiş, henüz SSCB rejiminin devam ettiği o dönemde bu kavram dünya kamuoyunda geniş yankilar uyandırmıştır. Kavram, o günden bugüne Türkiye literatüründe canlılığını korumuş olsa da toplumun geniş kesimleri (avam) tarafindan duyulması Erdoğan'ın bu kavramı kullanmasıyla olmuştur denilebilir. Erdoğan, Mankurt kavramını ilk olarak 20 Eylül 2015'te İstanbul Yenikapı'da düzenlenen mitingde kullanmış, bu tarihten sonra da kavram Türk basınında sıkça kullanılmıştır.

\section{Çalışmanın Soruları}

Çalışmanın amacına yönelik aşağıdaki sorular ölçüt alınmışıır.

- Mankurt kavramı hangi gazetelerin ana sayfasında yer almıştır, hangi gazeteler görmezden gelerek kavrama ana sayfasında hiç yer vermemiştir?

- İçinde Mankurt kavramının geçtiği haber, gazetelerin ana sayfasında nasıl konumlandırılmıştır? (manşette, alt manşette, sürmanşette, alt kuşakta, orta kuşakta gibi).

- Gazetelerin sahiplik yapıları ve ideolojileri dikkate alındığında ilgili habere yaklaşımları nasıldır? (gazetelerin iktidara yakın olup olmamalarına göre haberi ele alış biçimleri).

- İçinde Mankurt kavramının geçtiği habere gazetelerin ana sayfalarında ne şekilde yaklaşılmıştır? (olumlu-olumsuz/ tarafli-tarafsiz)

- Gazeteler Mankurt kavramının geçtiği ilgili haberi ana sayfasında ne şekilde aktarmıştır, yazılan haberin niteliği nasıldır? (iddia, bilgilendirme, açıklama gibi özelliklerinin kullanılıp kullanılmadiğı).

\section{Gündem Oluşturma Kuramı}

Gündem oluşturma kuramı temelde kitle iletişim araçlarının (KİA) bazı konulara ağıllık vererek kamuoyunun gündemini belirlediği görüşüne dayanmaktadır. Bu görüşün temelleri Birinci Dünya Savaşında gazete ve radyoların etkin propaganda gücü ile kitleleri etkilemesine dayanmaktadır. 1920'lerden 1940'lara kadar kamuoyu oluşumunda KİA'nın gündem belirlemede etkin gücünün olduğu kabul edilmiştir. Dünya savaşlarının kötü sonuçları kamuoyunda medyanın bu etkin gücüne olan inancı da olumsuz etkilemiş 1960 'lı yıllara kadar KİA’nın sanıldığı kadar etkili bir gücünün olduğu tartışılmıştır. Televizyonun yayın dünyasına girmesiyle KİA'nın kanaatleri etkilediği ve kamuoyu oluşturduğu fikri tekrar yaygınlık kazanmıştır (Bayram, 2015, s. 407-408).

Gündem oluşturma kuramına yönelik ilk çalısmalar 1922 yllında Walter Lippmann'ın yayınlamış olduğu Kamиoyu isimli eserine dayandırılsa da modern anlamda teorinin en önemli isimleri, hatta kurucular1 kabul edilen ve 1968 yilında Chapel Hill, North Carolina'daki kararsız seçmenler üzerinde yapmış oldukları çalışma ile Maxwell McCombs ve Donald Shaw teorinin temellerini atmışlardır. Araştırmacılar, 1968 yılında ABD'de yapılan başkanlık seçimleri kampanyalarında medyanın politik tutumları etkilediğine yönelik hipotezlerini öne sürmüşlerdir. Çalışmalarını bir grup kararsız seçmen örneklemi üzerinde yürüten teorisyenler KİA’nın gündem belirleme etkisini ölçmek için seçtikleri bazı gazeteler, haber dergileri ve televizyonların öne çıardığı söylemler üzerine içerik analizi uygulamışlar, KİA’nın öne çıkardığı gündem ile örneklem alınan grup arasındaki etkileşimi ölçümlemişlerdir. Bu çalşşa teorisyenlerin gündem oluşturma kuramını desteklemiş, bir konunun medyada vurgulanması ile o konun önemli olarak algılaması arasında doğrudan bir ilişki saptamışlardır (Gencer, 2012, s. 4748). Böylece gündem oluşturma kuramının ilk sistematik çalışmasını 1972 yılında McCombs ve Shaw yazmıştır. Bu teorisyenler, KİA’nın insanlara ne düşüneceklerini olmasa da ne hakkında düşüneceklerini başarllı bir şekilde empoze eden en önemli argüman olduğu ortak fikrini ortaya koymuşlardır.

Gündem oluşturma kuramı üzerine Türk basını ve Türk kamuoyu üzerine araştırmaları olan Nurettin Güz'de kamuoyunun oluşturulmasında KİA'nın önemine dikkat çekmiş, basın organlarının siyasal ve aktüel konularda kamuoyunun neyi ne kadar bilmesi gerektiğini belirlediğini, basının gündeme aldığı ve ağırlık verdiği konuların kamunun da gündemi olduğunu ileri sürmüştür (Güz, 1996, s. 995). Her medya grubu gündem belirler mi gibi bir soruya verilebilecek cevap gücü nispetinde evettir. Yani kamuoyunun gündemini medya sektörünün güçlüleri ve oralarda istihdam edilen etkili eşik bekçileri belirler demek yanlış olmayacak bir yargidir. 


\section{Bulgular}

Mankurt kavramı 1980'li yıllarda çokça gündeme gelmiş, o dönemde gerek edebiyat çevrelerinde gerekse siyasette büyük yankılar uyandırmıştır. Sonraları ise kavram, sözü edilen roman bağlamında edebiyatseverlerce diri tutulmuş, akademik camiada konuyla ilgili pek çok yayın yapılmışıı (Çınar, 2012; Çetin, 2013; Azap, 2017). Kavram, romandaki anlatıdan hareketle popüler gündemde ki kalem erbabınca da muhtelif zamanlarda farklı mecralarda da tefrika edilmiştir (Turan, 2008, 2015; Bahadıroğlu, 2015; Bulut, 2015; Yalçın, 2015; Önkibar, 2016; Taşgetiren, 2017; Şimşirgil, 2017; Özkök, 2018 vd.).

Kavramın Türkiye'de medya gündemi olması ise Erdoğan'ın kavramı kullanmasıyla gerçekleşmiştir. Erdoğan, 7 Haziran 2015 seçimlerinden sonra ülkede artan terör eylemleri akabinde çok sayıda vatandaşın hayatını kaybetmesi nedeniyle teröre karşı halkın birlik ve beraberliğini göstermek ve terörü telin etmek maksadıyla büyük bir mitingin organize edilmesini talep etmiştir.

Erdoğan, 20 Eylül 2015 tarihinde organize edilen büyük mitingdeki konuşmasında "Kim ki bu bayrağa yan gözle bakiyorsa, bu vatanla da bu milletle de bağg kalmamıs olan, köksï̈z, rubsuz, sevgisiz, bir Mankurttur (Milliyet, 2015).” ifadelerini kullanmıştır. Bu ifadeler akabinde Türk medyasının değissik mecraları; geleneksel medya, internet yayınları, Wikipedia ve Google gibi uluslararası arama motorları Mankurt kavramını gündeme taşımış, kavram ve kaynağına dair pek çok yazı neşredilmiştir.

Görsel 1. Türk Ulusal Yaz̨l Basmmnda Mankurt Metaforunun Gündeme Gelmesi

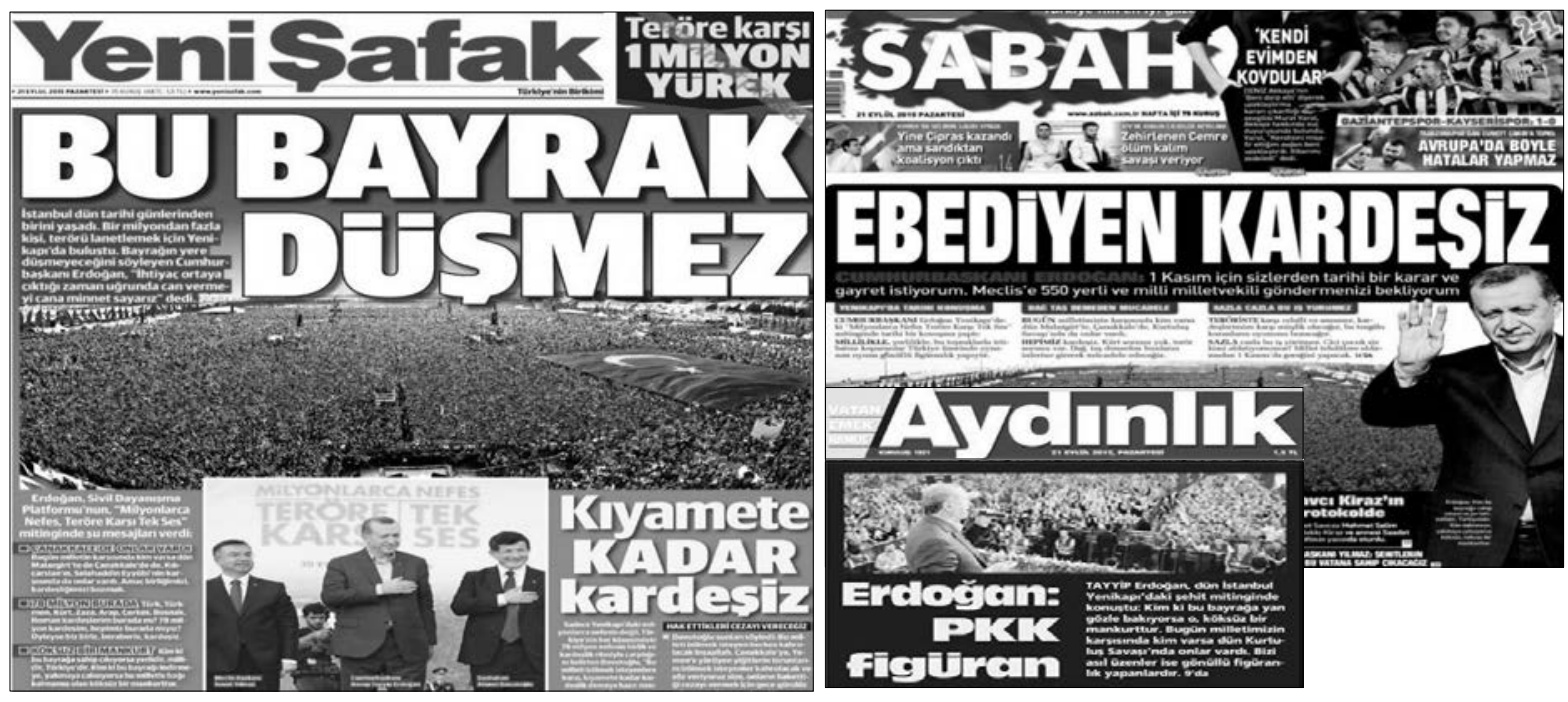

İnternet üzerinden yapılan taramalarda elde edilen bulgulara göre Erdoğan'ın Mankurt kavramını ilk kez bu mitingde kullanmış olabileceği kuvvetli bir ihtimaldir. Miting, hem ana akım gazetelerde, hem de taraf ve muhalif kabul edilen basında büyük ilgi uyandırmıs, gazeteler birinci sayfalarında mitinge dair haberlere yoğun bir şekilde yer vermiştir. Mankurt metaforu mitingin yoğun gündeminin gölgesinde kalmış kullanıldığı ilk anda yazılı basının dikkatini çok fazla çekmemiş̧ir. Sadece birkaç gazete kavrama birinci sayfasında yer vermiştir (bakınız Görsel 1 ve Tablo 1). 
Tablo 1. Mankurt Kavramınn Türk Yąıl Basınına Birinci Yansıması

\begin{tabular}{|c|c|c|c|c|}
\hline \multicolumn{5}{|c|}{21 Eylül 2015 Tarihli Gazetelerin Birinci Sayfasında Mankurt Metaforuyla İlgili Çıkan Haber Başlıkları } \\
\hline No & Tatih & Habetin Başlı̆g & Sayfadaki Yeri & Niteliğ $i$ \\
\hline 1. & Akşam & (İlgili haberde Mankurt kavramı yok) & Manşet & Olumlu \\
\hline 2. & Aydınlık & Erdoğan: PKK figüran & Üst kuşak haber içinde & Nötr \\
\hline 3. & Bir Gün & (İlgili haberde Mankurt kavramı yok) & Manşet & Olumsuz \\
\hline 4. & Bugün & (İlgili habere yer verilmemiş.) & & \\
\hline 5. & Cumhuriyet & (İlgili haberde Mankurt kavramı yok) & Alt kuşak & Olumsuz \\
\hline 6. & Diriliş Postas1 & (İlgili haberde Mankurt kavramı yok) & Manşet & Olumlu \\
\hline 7. & Evrensel & (İlgili haberde Mankurt kavramı yok) & Manşet üstü & Olumsuz \\
\hline 8. & Güneş & (İlgili haberde Mankurt kavramı yok) & Manşet & Olumlu \\
\hline 9. & Haber Türk & (İlgili haberde Mankurt kavramı yok) & Manşet & Olumlu \\
\hline 10. & Hürriyet & (İlgili haberde Mankurt kavramı yok) & Manşet & Nötr \\
\hline 11. & Meydan & (İlgili haberde Mankurt kavramı yok) & Orta kuşak & Olumsuz \\
\hline 12. & Milat & (İlgili haberde Mankurt kavramı yok) & Manşet & Nötr \\
\hline 13. & Millet & (İlgili haberde Mankurt kavramı yok) & Alt kuşak & Olumsuz \\
\hline 14. & Milli Gazete & (İlgili haberde Mankurt kavramı yok) & Alt kuşak & Nötr \\
\hline 15. & Milliyet & (İlgili haberde Mankurt kavramı yok) & Üst kuşak & Nötr \\
\hline 16. & Ortadoğu & (İlgili haberde Mankurt kavramı yok) & Manşet & Olumsuz \\
\hline 17. & Özgür Gündem & (Ilgili haberde Mankurt kavramı yok) & Alt kuşak & Olumsuz \\
\hline 18. & Posta & (Ilgili haberde Mankurt kavramı yok) & Orta kuşak & Nötr \\
\hline 19. & Sabah & Ebediyen Kardeşiz & Manşet/ Fotoğraf altı & Olumlu \\
\hline 20. & Sözcü & (İlgili haberde Mankurt kavramı yok) & 2. Manşet & Nötr \\
\hline 21. & Star & (İlgili haberde Mankurt kavramı yok) & Manşet & Olumlu \\
\hline 22. & Takvim & (Ilgili haberde Mankurt kavramı yok) & Manşet & Olumlu \\
\hline 23. & Taraf & (İlgili haberde Mankurt kavramı yok) & Manşet & Olumsuz \\
\hline 24. & Türkiye & (İlgili haberde Mankurt kavramı yok) & Manşet & Olumlu \\
\hline 25. & Vahdet & (İlgili haberde Mankurt kavramı yok) & Sürmanşet & Olumlu \\
\hline 26. & Vatan & (İlgili haberde Mankurt kavramı yok) & Manşet & Olumlu \\
\hline 27. & Önce Vatan & (Ilgili haberde Mankurt kavramı yok) & Manşet & Olumlu \\
\hline 28. & Yeni Akit & (İlgili haberde Mankurt kavramı yok) & Manşet & Olumlu \\
\hline 29. & Yeni Asya & (İlgili habere yer verilmemiş.) & & \\
\hline 30. & Yeniçağ & (İlgili haberde Mankurt kavramı yok) & Alt kuşak & Olumsuz \\
\hline 31. & Yeni Söz & (İlgili haberde Mankurt kavramı yok) & Alt kuşak & Olumlu \\
\hline 32. & Yeni Şafak & Bu bayrak düşmez & Manşet haberi içinde & Olumlu \\
\hline 33. & Yurt & (İlgili haberde Mankurt kavramı yok) & Manşet & Olumsuz \\
\hline 34. & Zaman & (Ilgili haberde Mankurt kavramı yok) & Alt kuşak & Olumsuz \\
\hline
\end{tabular}

Görsel 1 ve Tablo 1 incelendiğinde kavrama sadece Sabah, Yeni Şafak ve Aydnllk gazetelerinin yer verdiği görülmüştür. Bu gazetelerden Sabah ve Yeni Şafak'ın kamuoyunda hükümet yanlısı yayınlar yaptıkları iddia edilirken, Aydnhlı gazetesi ise ulusalcı sol yayınlarıyla ön plana çımaktadır. Mankurt metaforunu üç gazetede Erdoğan'ın ağzından çıktığı gibi aynı cümlelerle vermiştir. Sabah gazetesi kavramın geçtiği cümleyi Erdoğan'ın fotoğrafı altında verirken, Yeni Şafak gazetesi ise kavramı manşet içinde "Köksüz Bir Mankurt" alt başlığı ile vermiştir. Aydnnlk gazetesi ise "Erdoğan: PKK Figüran" haberi içinde kavrama yer vermiştir.

Tablo 1'de dikkat çeken başka unsurlarda vardır. Mitingin ertesinde yayımlanan gazetelerin neredeyse tamamı mitingi haberleştirirken FETÖ'ye yakınlığılla bilinen Bugün gazetesi ve Yeni Asya gazetelerinde miting haberine hiç yer verilmemiştir. FETÖ'nün 15 Temmuz 2016'daki darbe girişimine yayınlarıyla destek verdikleri için KHK ile kapatılan Zaman, Millet, Meydan ve Taraf gazeteleri ise miting haberini çok küçük şekilde ve iktidar aleyhine olumsuz nitelikte birinci sayfadan vermiştir. Merkez medya ya da ana akım kabul edilen gazeteler (Hürriyet, Milliyet, Habertürk ve Vatan) ise mitingle ilgili haber ve görsellere ana sayfalarında oldukça geniş şekilde ve olumlu imaj oluşturacak biçimde yer vermişlerdir. İktidara doğrudan muhalif yayınlarıyla bilinen gazeteler (Sözcü, Cumburiyet, Bir Gün, ve diğerleri) ise birinci sayfalarında Erdoğan’ı "miting adı altında seçim şovu yapıyor" şeklinde eleştirmişlerdir.

Miting ertesinde yayınlanan 21 Eylül 2015 tarihli gazetelerin birinci sayfasında genel olarak mitinge katılım oranları ve organizasyondan görüntülere yer verilmiştir. Manşetlere teröre karşı toplumdan 
yükselen telinler, toplumun birlik içinde kenetlenmesi gibi konular taşınmıştır. Küçük spotlarla da cumhurbaşkanın, başbakanın ve diğer devlet erkânının konuşmalarının satırbaşları verilmiştir. Mankurt kavramı genel olarak basılı gazetelerin ana sayfalarında yer bulamamıştır. Fakat gün içerisinde internet medyasında çıkan haberlerde cumhurbaşkanın kullandığ Mankurt ifadesi yoğun bir şekilde gündem olmuş, "Erdoğan Mankurt dedi, herkes sözlüğe baktı" şeklinde başlıklar atılmıştır. Mitingin ertesinde 21 Eylül 2015 tarihinde internet gazeteleri "Erdoğan'in kullandığı Mankurt ifadesi gündem oldu/ Yeni Şafak", "Mankurt ifadesi yeniden gündemde/ Milliyet", "Erdoğan'in söylediği Mankurt kimdir?/ İnternet Haber", "Mankurt nedir, kimlere denir? Erdoğan, kimler için Mankurt dedi?/ Sözcü" şeklinde haber başlikları atılmış, Mankurt’un ne olduğu, nereden çıktı̆̆ üzerine geniş açıklamalar yapılmıştır (bakınız Görsel 2). Görsel 1'de görüldüğü üzere baskı gazeteler Mankurt kavramını ön plana çıkartmazken internet medyas1 kavram üzerine oldukça geniş yayınlar yapmıştır (Görsel 2).

Görsel 2. Mankurt Metaforunun Internet Medyasinda Gündeme Gelmesi

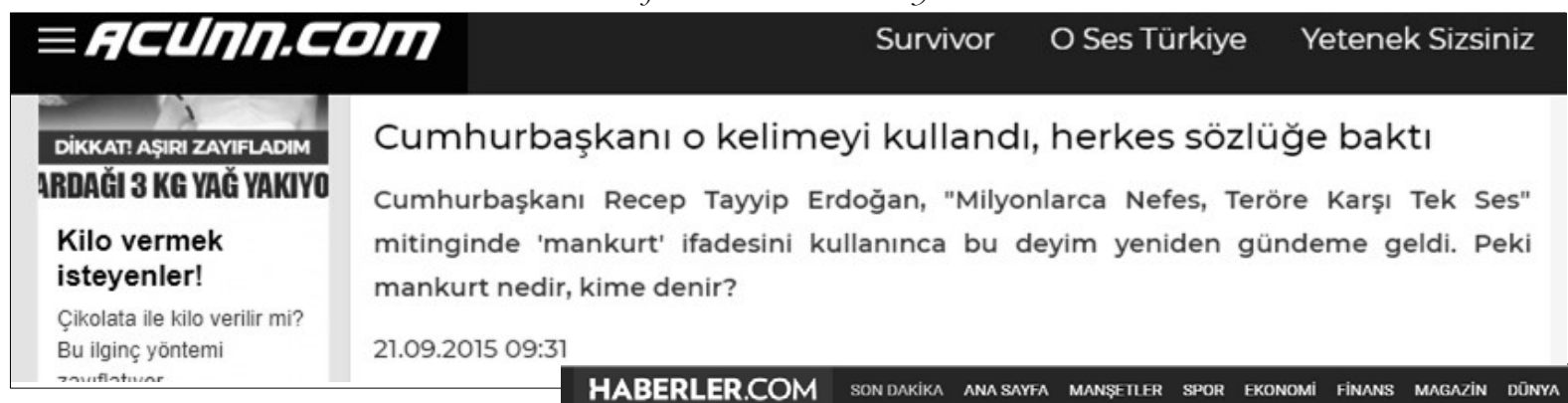

Cumhurbaşkanı Erdoğan

\section{Mankurt nedir, kimlere denir? Erdoğan, kimler için Mankurt dedi?}

Cumhurbaşkanı Erdoğan, pazar günü yapılan mitingte kime mankurt dedi? Mankurt nedir? Mankurt kimlere söylenir? Mankurt nasıl yapılır?

\section{SIYASET \\ Milliyet.com.tr $\gg$ Siyaset Haber $\approx$ Mankurt ifadesi y \\ 21.09.2015 08:37 | Son Güncelleme:21.09.2015-9:30}

Mankurt ifadesi yeniden gündemde

Cumhurbaşkanı Recep Tayyip Erdoğan, "Milyonlarca Nefes, Teröre Karşı Tek Ses" mitinginde 'mankurt' ifadesini kullanınca bu deyim yeniden gündeme geldi. Peki mankurt nedir, kime denir?
Erdoğan'ın kullandığı 'Mankurt' ifadesi yeniden gündemde

Cumhurbaşkanı Erdoğan, "Milyonlarca Nefes, Teröre Karşı Tek Ses'

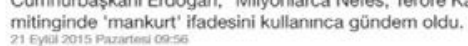




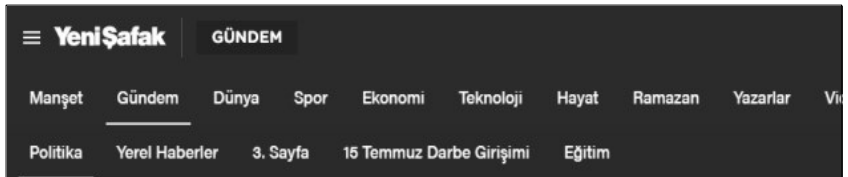
poutinia

\section{Erdoğan'ın kullandığı 'mankurt'} ifadesi gündem oldu

Cumhurbaşkanı Recep Tayyip Erdoğan, "Milyonlarca Nefes, Teröre Karşı Tek Ses" mitinginde 'mankurt' ifadesini kullanınca bu deyim yeniden gündeme geldi. Peki mankurt nedir, kime denir?

1

Erdoğan'ın ilk olarak 20 Eylül 2015'te kullandığı Mankurt kavramını 19 Ekim 2015'te yani tam bir ay sonra yeniden kullanmıştır. Erdoğan'ın kamuoyu önünde ikinci kez Mankurt metaforunu kullanması Türk ulusal basının oldukça dikkatini çekmiş, hemen hemen her meşrepten gazete kavrama birinci sayfasında yer vermiștir. Hatta bazı gazeteler "Mankurtlar" manșeti ile çıkmıștır. Kavramın bu kadar üst perdeden ülke gündemine gelmesini sağlayan ve Erdoğan'n Mankurt metaforunu kullanmasını gerektiren olay 20 Ekim 2015 tarihinde Almanya Başbakanı Angela Merkel'in Türkiye'ye yaptığ ziyaretin öncesinde 100 kadar akademisyenin ve yazarın Merkel'e "bu ziyaretin 1 Kasım 2015 seçimlerinin hemen öncesinde yapılması Erdoğan ve partisine destek anlamı taşır. Bu ziyaretinizi seçim sonrasına erteleyiniz" mealinde bir mektup yazmalarıdır. Bu mektupta akademisyen ve yazarların Merkel'e özetle "Saym Angela Merkel, Size modern

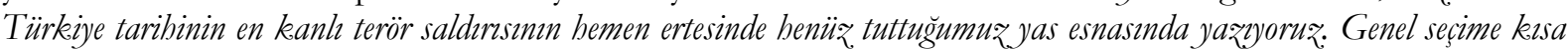
bir süre kalmışken ülkemize yapacağmnz, ziyarette dikekatinizi çekmek istediğimiz. önemli bir busus var... Bu bağlamda yapacağınz ziyaretin kampanya ikliminde siyasi bir destek olarak görüleceüinden ve AB'nin en önemli değerlerini şiğneyen siyasetçileri taltif etme ibtimalinizden dolay akademisyenler olarak. fevkalade rahatsızı: Sn. Erdoğan ve Sn. Davutoğlu ile yapacağm günlerde de ziyaret etmenizi umarz. (Cumburiyet, 2015)." şeklinde istirhamda bulunmalar1 Erdoğan'in tepkisin çekmiştir. Erdoğan, 19 Ekim 2015'te Beştepe Külliyesinde geleneksel hale getirdiği muhtarlar toplantısındaki konuşmasında: "Almanya Başbakan Türkiye'ye geliyor. Bir güruh çııı 'Gelmeyin, bu Erdoğan ve Davutoğlu'na destek anlamına gelir' diyor. Bu girișimin adn 5. kol faaliyetidir. Bu girișimdekilere ben Mankurt diyorum (Sabah, 2015)." şeklinde sert ifadelerle Merkel'e mektup yazan yazar ve akademisyenleri eleștirmiş, onları Mankurta benzetmiștir.

Erdoğan'ın 19 Ekim 2015 tarihinde muhtarlar toplantısında dile getirdiği “5. kol faaliyeti ve Mankurt” metaforları 20 Ekim tarihli 15 gazetenin birinci sayfasına Görsel 3 ve Tablo 2'deki gibi yansımıştır. Erdoğan'ın konuşmasına birinci sayfasından yer veren bazı gazeteler Mankurt metaforunu manşet olarak kullanırken, bazları ilgili habere yer vermişse de kavrama yer vermemiş, kimi gazeteler ise ilgili kavramın geçtiği haberi sayfalarında çok küçük şekilde vermişlerdir. Erdoğan'a ve hükümetinin politikalarına yakın olduğu iddia edilen ${ }^{5}$ Sancak (Star, Akșam, Güneş) ve Turkuvaz (Sabah, Takvim, Yeni Asır) medya gruplarında yer alan gazeteler Mankurt metaforunu manşetten veya manşet içinden görünür şekilde verirken Cumburivet, Bir Gün gibi sol tandanslı gazeteler ise birinci sayfadan fakat olabildiğince küçük șekilde vermişlerdir (bakınız Görsel 3). Merkez medya olarak bilinen ve daha liberal oldukları kabul edilen (Hürriyet, Posta), (Habertürk) ve (Milliyet, Vatan) gazeteleri kavramın geçtiği haberi orta düzeyden görünür şekilde verirken popülist muhalefet gazetesi Sö̊çü kavramı 2. manşet şeklinde vermiştir. Mankurt kavramını sayfalarına nerdeyse hiç taşımayan medya grubu ise kedilerinin "Camia" hükümetin ise paralel yap1 dediği 15 Temmuz 2016'dan sonra ise silahlı terörü örgütü olarak kabul edilen ve PDY/FETÖ olarak adlandırlan yapının gazeteleri Zaman, Bugün, Meydan ve Millet gazeteleridir. Bu gazeteler ilgili habere ve kavrama birinci sayfalarında hiç yer vermemişlerdir. Yine aynı șekilde milliyetçi yayınlar yapan Ortadoğu ve Yeniçă̆ gazeteleri ile İslami çizgide yayın yapan Yeni Asya, Vahdet, Milli Gaz̨ete de ilgili kavramın geçtiği haberi birinci sayfalarında paylașmamıșlardır (bakınız Görsel 3 ve Tablo 2).

\footnotetext{
5 Türkiye'de medyanın sahiplik yapısı devamlı değişmekte olup, bazı medya organları, KHK'larla bazıları da kendilerini feshetmek yoluyla yayıncılık hayatından çıkmışlardır. Türkiye'de 2017 ve 2018 yılında da Türk medyasının sahiplik yapısında ve yayıncılık hayatında köklü değişmeler devam etmiş, ülkenin en güçlü ve köklü medya grubu Doğan Holding, Demirören grubuna satıllırken, Ciner grubunun gazetesi Habertürk'de kâğıda baskısını yayından kaldırarak dijital yayıncıllğa geçmiştir. Yine Ethem Sancak Yönetiminde bulunan Es Medya (Star Gazetesi, Akșam, Güneș, TV 360 ve Kanal 24'ün yanı sıra Lig Radyo ve bazı dergiler) 2017 yllında Hasan Yeşildağ’a satılmıştır.
} 
Mankurt metaforunu kullanan gazeteler Görsel 3’teki şekilde ilgili haberi sayfalarına taşımışlardır. Ak Partiyi ve Erdoğan'ı açıktan desteklediği iddia edilen Akşam gazetesi metaforu "Mankurtlar" manşetiyle verirken bir başka manşeti de Takvim gazetesi "İçimizdeki Yabancılar Mankurt" şeklinde vermiştir. Ana akım gazetelerden Hürriyet in diğer merkez medya gazetelerine göre haberi daha küçük verdiği dikkat çekerken, muhalif gazete Sözcï̀nün ikinci manşet olarak "Mankurt"u kullanması anlamlı bulunmuştur.

Görsel 3. Türk Ulusal Yažl Basinnda Mankurt Metaforunun Gündeme Gelmesi

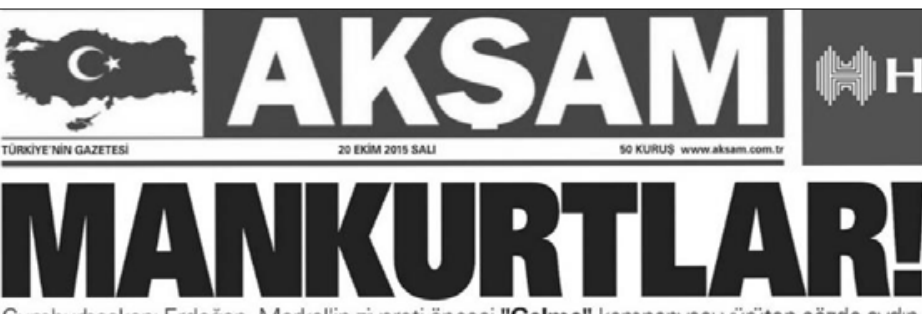

Cumhurbașkanı Erdoğan, Merkel'in ziyareti öncesi "Gelme" kampanyası yünüten sözde aydin ları, Orta Asya efsanelerinde "kişiliksizleștirilmiş köle" anlamına gelen mankurtlara benzetti.

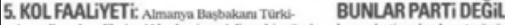

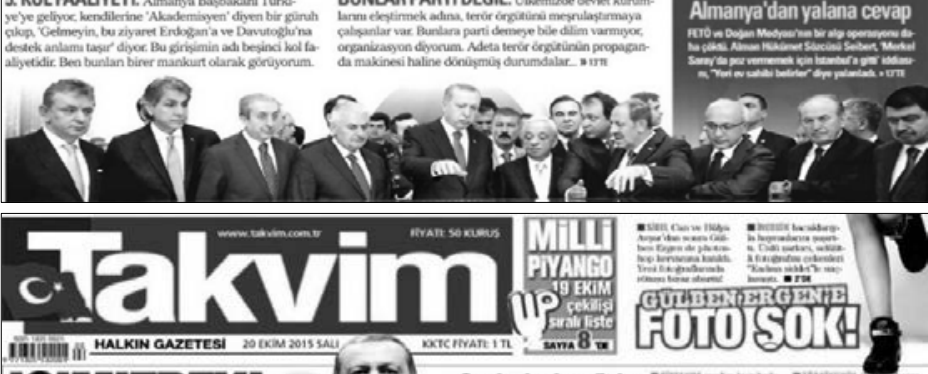
ICIMIZTEKI
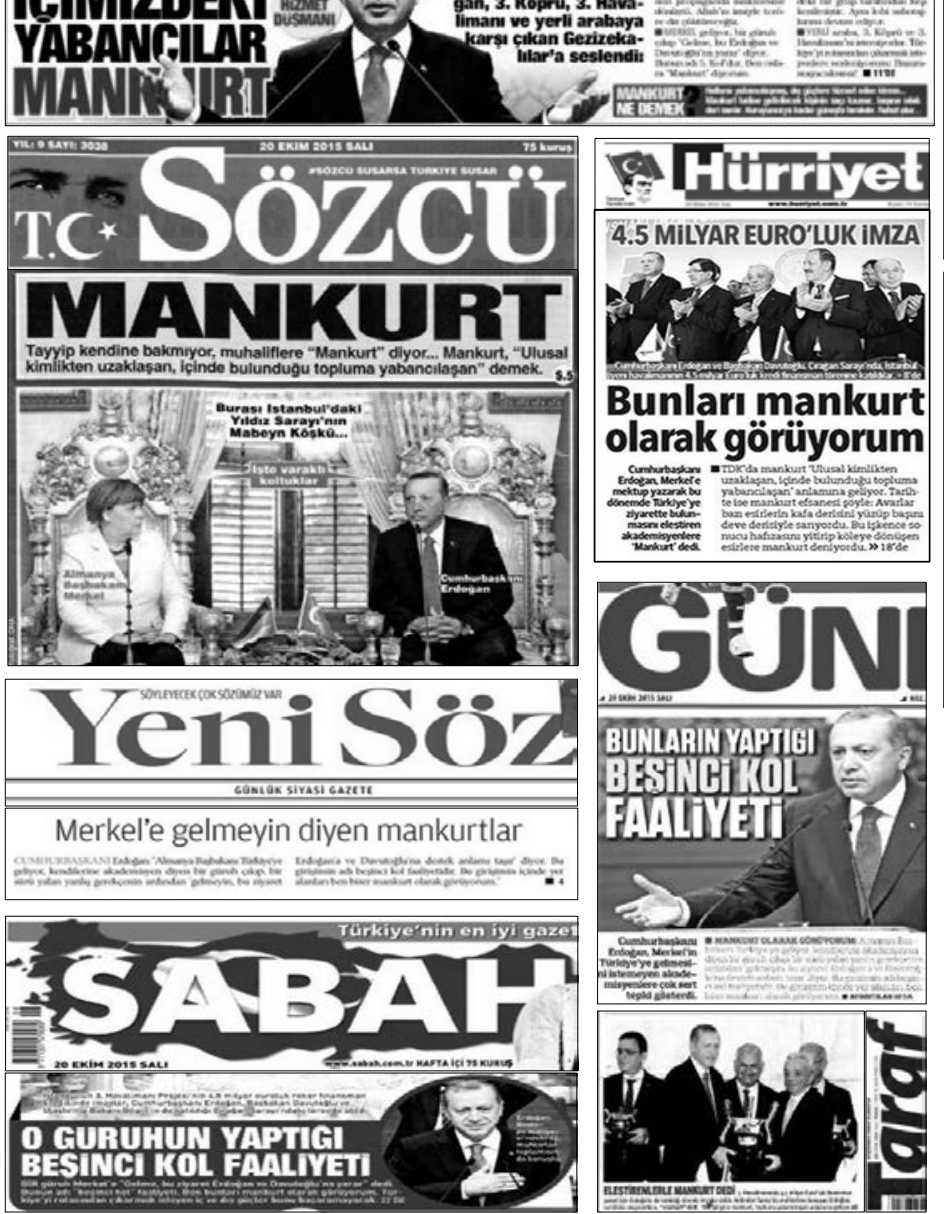

4Milliyet Bígün
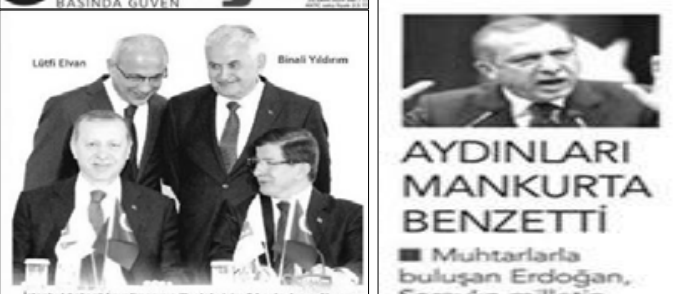

AYDINLARI

MANKURTA

BENZETTI

- Muhtarlarla

bulusan Erdogan.

Saray in milletin

ididia etti. Endogan.

Almanya Basbakan

Angela Merkel'in

Turkiye "ye gercek-

ilikin rahatsolik-

lanne dile getirdik-

leni mektuubu ima

'manicurt' diyorum-

Cumhuriyet

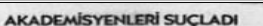

Cumhurbaskanı

Mankurt' dedi

3. havalimanina $\mathrm{HAB}: \mathrm{Z}$ finansman tamam $\mathbf{T} \mathbf{U R \mathbf { K }}$

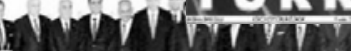

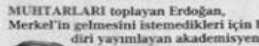

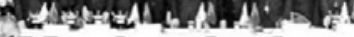
'Mankurt' çוkıŞı

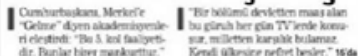

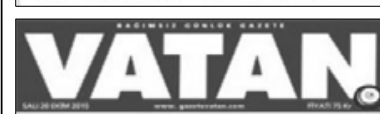

‘CILGIN' KREDI 4.5 MITYAR EURO apponat?
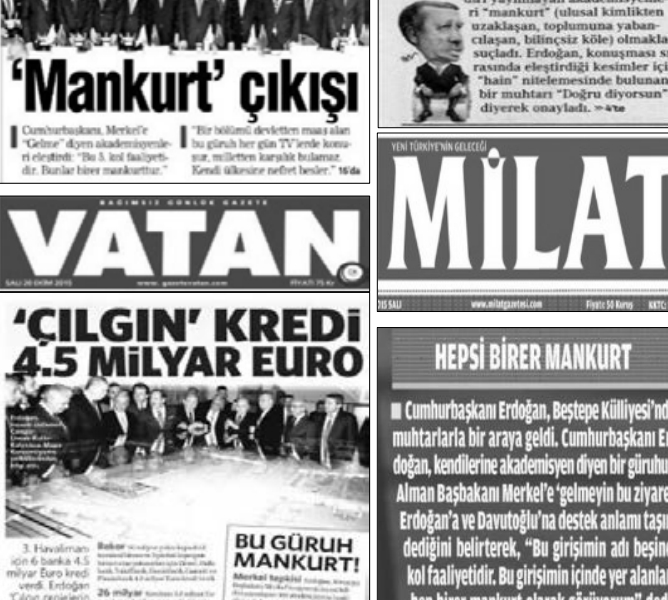

1.2.
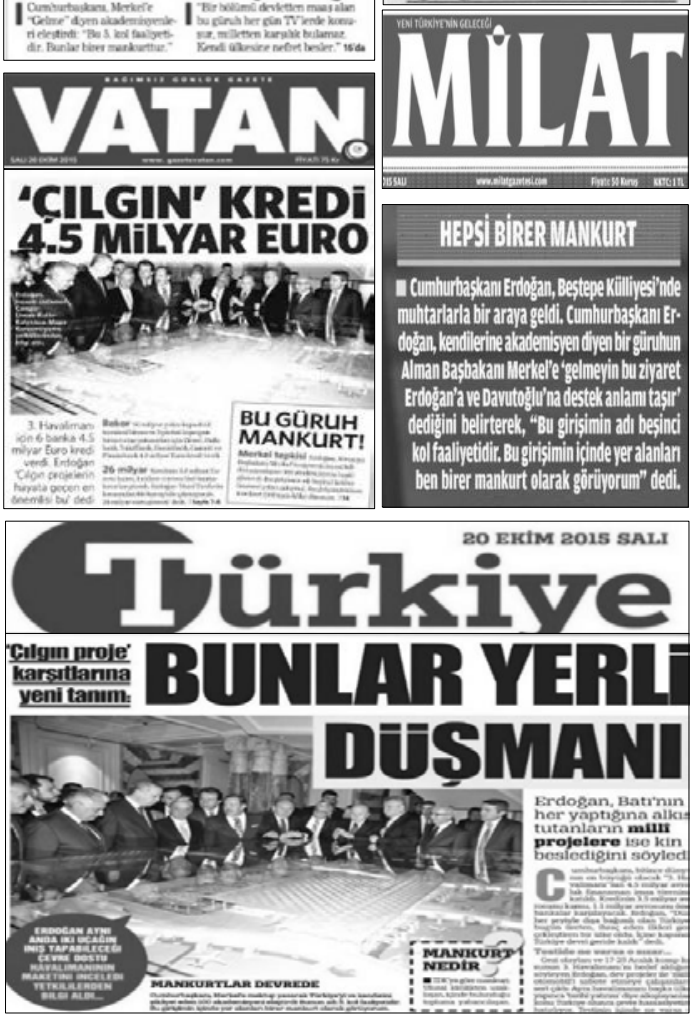
Tablo 2. Mankurt Kavrammm Türk Yaz̨l Basmma İkinci Yansıması

\begin{tabular}{|c|c|c|c|c|}
\hline \multicolumn{5}{|c|}{20 Ekim 2015 Tarihli Gazetelerin Birinci Sayfasında Mankurt Metaforuyla İlgili Çıkan Haber Başlıkları } \\
\hline No & Tarih & Haberin Basliğ & Sayfadaki Yeri & Niteliği \\
\hline 1. & Akşam & Mankurtlar! & Manşet & Olumlu/Taraflı \\
\hline 2. & Aydınlık & (İlgili habere yer verilmemiş.) & & \\
\hline 3. & Bir Gün & Aydınları Mankurta Benzetti & Orta kuşak & Olumsuz/ Taraflı \\
\hline 4. & Bugün & (İlgili habere yer verilmemiş.) & & \\
\hline 5. & Cumhuriyet & Cumhurbaşkanı Mankurt Dedi & Orta kuşak & Nötr \\
\hline 6. & Diriliş Postas 1 & (İlgili haberde Mankurt kavramı yok) & Manşet & Olumlu \\
\hline 7. & Evrensel & (İlgili habere yer verilmemiş.) & & \\
\hline 8. & Güneş & Bunların yaptı̆̆ beşinci kol faaliyeti & Üst kuşak & Olumlu/ Taraflı \\
\hline 9. & Haber Türk & Mankurt Çıkışı & Alt kuşak & Nötr \\
\hline 10. & Hürriyet & Bunları Mankurt Olarak Görüyorum & Alt kuşak & Nötr \\
\hline 11. & Meydan & (İlgili haberde Mankurt kavramı yok) & Manşet & Olumsuz \\
\hline 12. & Milat & O Tuzaklara Siz Düşeceksiniz & Manşet içinde & Olumlu \\
\hline 13. & Millet & (İlgili habere yer verilmemiş.) & & \\
\hline 14. & Milli Gazete & (İlgili habere yer verilmemiş.) & & \\
\hline 15. & Milliyet & Bunlar Mankurt & Üst kuşak & Nötr \\
\hline 16. & Ortadoğu & (İlgili habere yer verilmemiş.) & & \\
\hline 17. & Sabah & O Güruhun Yaptığ1 Beşinci Kol Faaliyeti & Manşet içinde & Olumlu \\
\hline 18. & Sözcü & Mankurt & Manşet altı & Nötr \\
\hline 19. & Star & (İlgili haberde Mankurt kavramı yok) & Sürmanşet & Olumlu \\
\hline 20. & Takvim & İçimizdeki Yabancılar Mankurt & Manşet & Olumlu \\
\hline 21. & Taraf & 3. Havaalanı Beyaz Fil Mi? & Haber içinde & Olumsuz/ Taraflı \\
\hline 22. & Türkiye & Bunlar Yerli Düşman/ Mankurt nedir & Manşet içinde & Olumlu/ Taraflı \\
\hline 23. & Vahdet & (İlgili habere yer verilmemiş.) & & \\
\hline 24. & Vatan & Bu Gürüh Mankurt & Manşet yanı & Olumlu/ Taraflı \\
\hline 25. & Yeni Akit & (İlgili haberde Mankurt kavramı yok) & & Olumlu \\
\hline 26. & Yeni Asya & (İlgili habere yer verilmemiş.) & & \\
\hline 27. & Yeniçağ & (İlgili habere yer verilmemiş.) & & \\
\hline 28. & Yeni Söz & Merkel'e Gelmeyin Diyen Mankurtlar & Orta kuşak & Olumlu/ Taraflı \\
\hline 29. & Yeni Şafak & (İlgili habere yer verilmemiş.) & & \\
\hline 30. & Yurt & (İlgili haberde Mankurt kavramı yok) & Manşet & Olumsuz \\
\hline 31. & Zaman & (İlgili habere yer verilmemiş.) & & \\
\hline
\end{tabular}

Görsel 3 ve Tablo 2'de dikkat çeken başka bir husus ise hükümete yakınlıklarıyla bilinen Sancak ve Turkuvaz gruplarına ait iki gazetenin "beşinci kol" ifadesini haber başlı̆ı olarak kullanmalarıdır. Aynı guruba ait gazetelerin gündem saptarken seçtikleri haberler, ve kullandıkları dil grupların eşik bekçileri tarafindan bir denge içinde taksim edilmiştir. Akșam gazetesi Mankurt ifadesini manşete taşırken Güneş gazetesi "Beşinci Kolb" ifadesini taşımıştır. Benzer durum Sabah gazetesi ile Takvim gazetesi arasında da görülmektedir.

\footnotetext{
${ }^{6}$ Beşinci kol, fiilî müdahale ile ele geçirilemeyen bir kitleyi ya da devleti propaganda, casusluk, sabotaj ya da terör yoluyla manevî etkiye maruz bırakmak suretiyle müdahaleye uygun hale getirmek ya da fiilì savaş esnasında savaşı daha kolay kazanmak için yapılan her türlü manevî yıkıcı çalışmadır (Wikipedia).
} 
Görsel 4. Türk Ulusal Yąllı Basininda Mankurt Metaforunun Gündeme Gelmesi
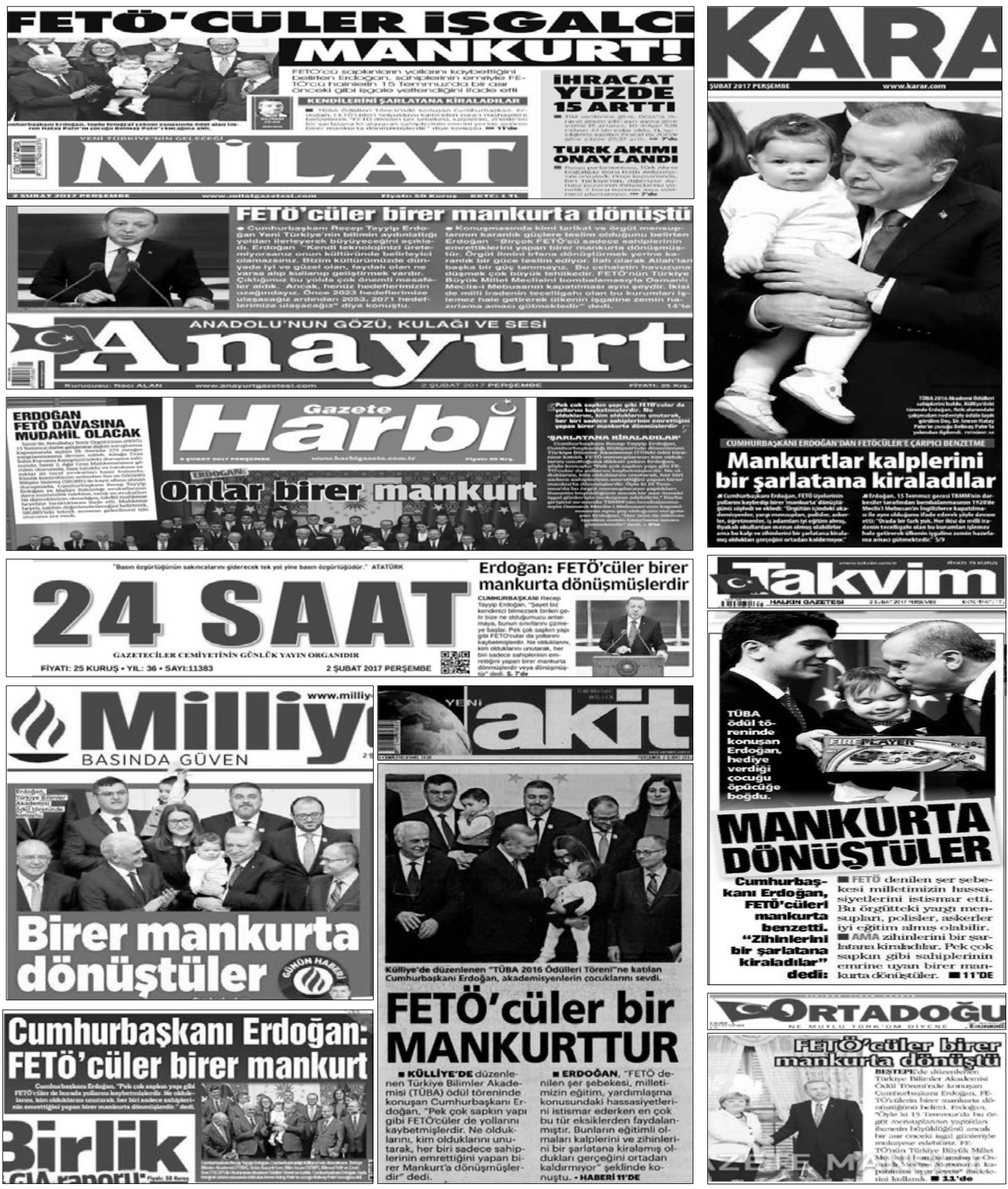


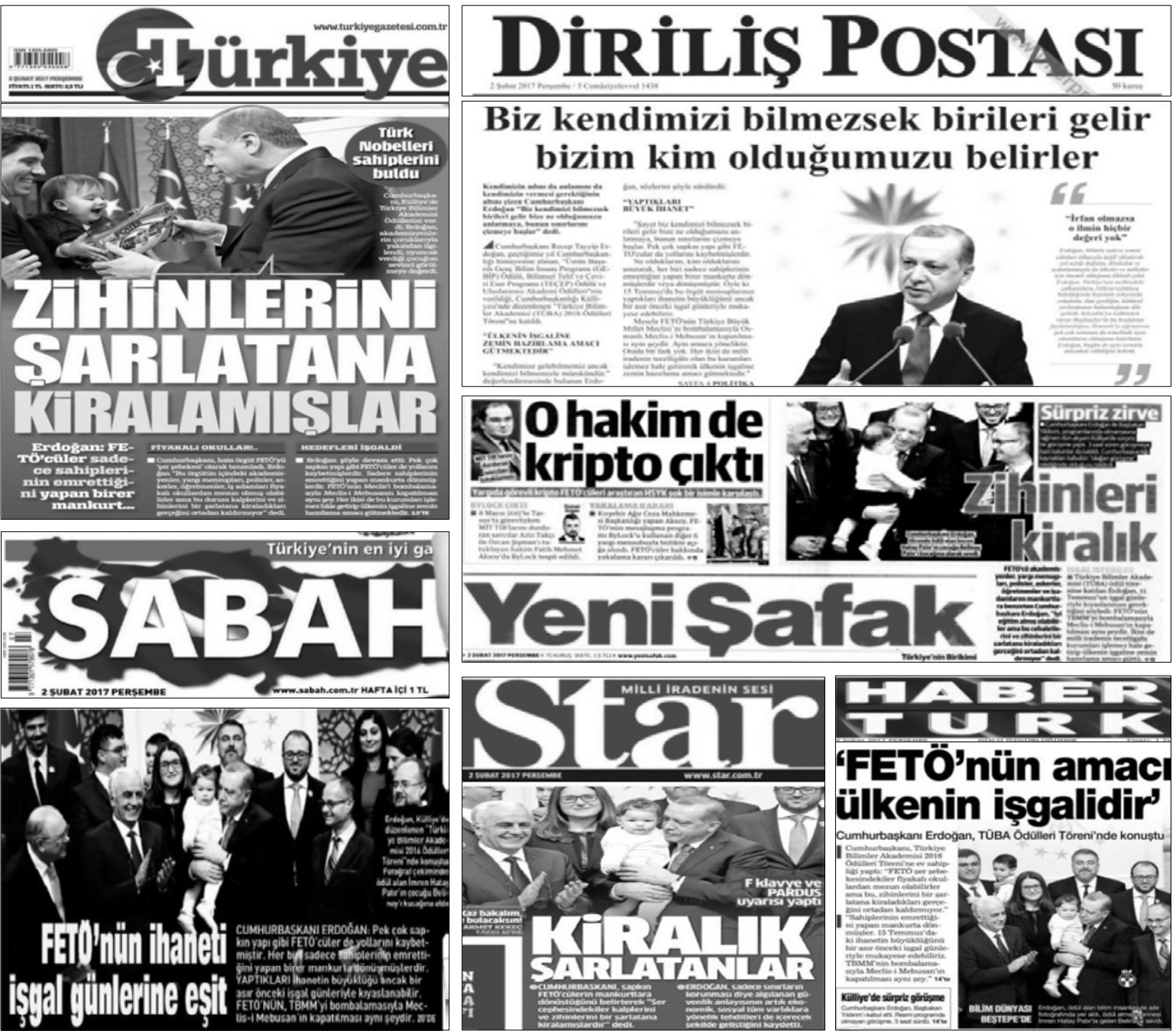

Mankurt metaforunu yazılı basının gündemine ilk olarak 2015 y1lında getiren Erdoğan, iki y1l sonra 1 Şubat 2017 yılında Cumhurbaşkanlığ1 Külliyesi’nde düzenlenen, Türkiye Bilimler Akademisi (TÜBA) ödül töreninde aynı metaforu FETÖ’yü hedef göstererek yeniden kullanmıştır. 'FETÖ denilen șer șebekesi, milletimiz̨in eğitim, yardımlaşma konusundaki hassasiyetlerini istismar ederken en çok bu tür eksiklerden faydalanmıstır. Bu örgütün içindeki akademisyenler, yarg mensuplar, polisler, askerler, ögretmenler, iş adamlar iyi eğitim almış, fiyakalı okullardan mezun olmus olabilirler ama bu durum bakikatler karsısindaki körlüklerini, cehaletlerini, kalplerini ve zibinlerini bir şarlatana kiralamıs oldukları gerçüini ortadan kaldırmıyor. Pek çok sapkın yapı gibi FETÖ'cüler de yollarm kaybetmislerdir. Ne olduklarm, kim olduklarm unutarak, her biri sadece sabiplerinin emrettiğini yapan birer Mankurta dönmüşlerdir (Yeni Akit, 2017).” Aradan geçen iki y1l içinde Türk medyasının sahiplik yapısında köklü değişimler olmuş, bu arada FETÖ ile iltisaklı gazeteler ve diğer medya organları çıarılan KHK'larla kapatılmış, ortalama 1 milyonluk gazete tirajı açıkta kalmıştır.

Erdoğan, Mankurt metaforunu bir önceki kullanımlarında da Şubat 2017’de de terörü ve terörle ilişkili kesimleri eleştirmek için kullanmıştır. Erdoğan 1 Şubat 2017 yılında Cumhurbaşkanlığı Külliyesi’nde yaptığ1 konuşmasında Mankurt kavramını kullanırken yine terörle ilişkisini kurmuş, kavramı bu sefer FETÖ/PDY için kullanmıştır. Bu dönem içinde FETÖ/PDY’ye destek veren gazeteler yayında olmadığ1 için yayında olan gazeteler analiz edilmiş, yapılan araştırmada ulusal yayın yapan 36 gazetenin yarıya yakını yani 16 gazete Erdoğan'ın sözlerinde vurguladığı Mankurt metaforunu birinci sayfalarında kullanmışlardır. 16 gazetenin 10 tanesi kavramı doğrudan haberin başlı̆̆1 içerisinde kullanırken 6 gazete de haberin içerisinde kavrama yer vermiştir. Bazı gazeteler ise kavrama yer vermeden ilgili haberi yayımlamıştır. İlgili haberi kavrama değinmeden birinci sayfadan veren 7 ulusal gazete tespit edilmiştir. Bu gazetelerle birlikte Türk ulusal medyasında 2017 yılı içinde yayın yapan gazetelerin üçte ikisi yani 22 gazete kavramla ilişkili haberi birinci sayfalarında gündeme taşımışlardır. Kavramı doğrudan haberin başlı̆̆ında sürmanşetten veren gazeteler Anayurt, Yeni Birlik ve Milat gazeteleri olurken, Harbi gazetesi aynı kavramı manşet olarak vermiştir. Dört gazetenin ortalama tiraj1 150 binin üzerindedir. 
Kavramı başlı̆̆ına taşıyan gazeteler: Anayurt: FETÖ’cüler Birer Mankurta Dönüstü, Harbi: Onlar Birer Mankurt, Karar: Mankurtlar Kalplerini Bir Şarlatana Kiraladilar, Milat: FETÖ'cüler Isgalci Mankurt, Milliyet: Birer Mankurt'a Dönüstüler, Ortadoğu: FETÖÖ'üler Birer Mankurt'a Dönüstü, Takvim: Mankurt'a Dönüstüler, Yeni Akit: FETÖ'cüler Bir Mankurttur, Yeni Birlik: Cumburbaşkan Erdoğan: FETÖ'cüler Birer Mankurt, 24 Saat: Erdoğan: FETÖ'cüler Birer Mankurta Dönüsmüsstür.

Haberin içinde kavrama yer veren gazeteler: Sabab: FETÖ’nün İhaneti İsgal Günlerine Eşit, Star: Kiralık Şarlatanlar, Türkiye: Zihinlerini Şarlatana Kiralamışlar, Yeni Şafak: Zihinleri Kiralık, Dirilis Postast: Biz Kendimizi Bilmezsek Birileri Gelir Kim Olduğumuzu Belirler, Habertürk: FETÖ’nün Amac1 Ülkenin İşgalidir.

Burada dikkat çeken unsur gazetelerin gündem belirlerken tamamen kendi meşrepleri, siyasal anlayışları çerçevesinde hareket etmiş olmalarıdır. Buna örnek olarak MHP'nin politikalarını destekleyen, MHP'nin medyadaki sesi konumundaki Ortadoğu gazetesi gösterilebilir. Gazete, hükümete muhalif yayınlar yaparken, 15 Temmuz 2016'dan sonra MHP'nin hükümetle ortak hareket etmesine paralel olarak Ortadoğu gazetesi de yandaş oldukları iddia edilen gazetelerle aynı başlığı atmıştır (bakınız Tablo 3).

Tablo 3. Mankurt Kavramının Türk Yaz̧lı Basımına Üçüncü Yansıması

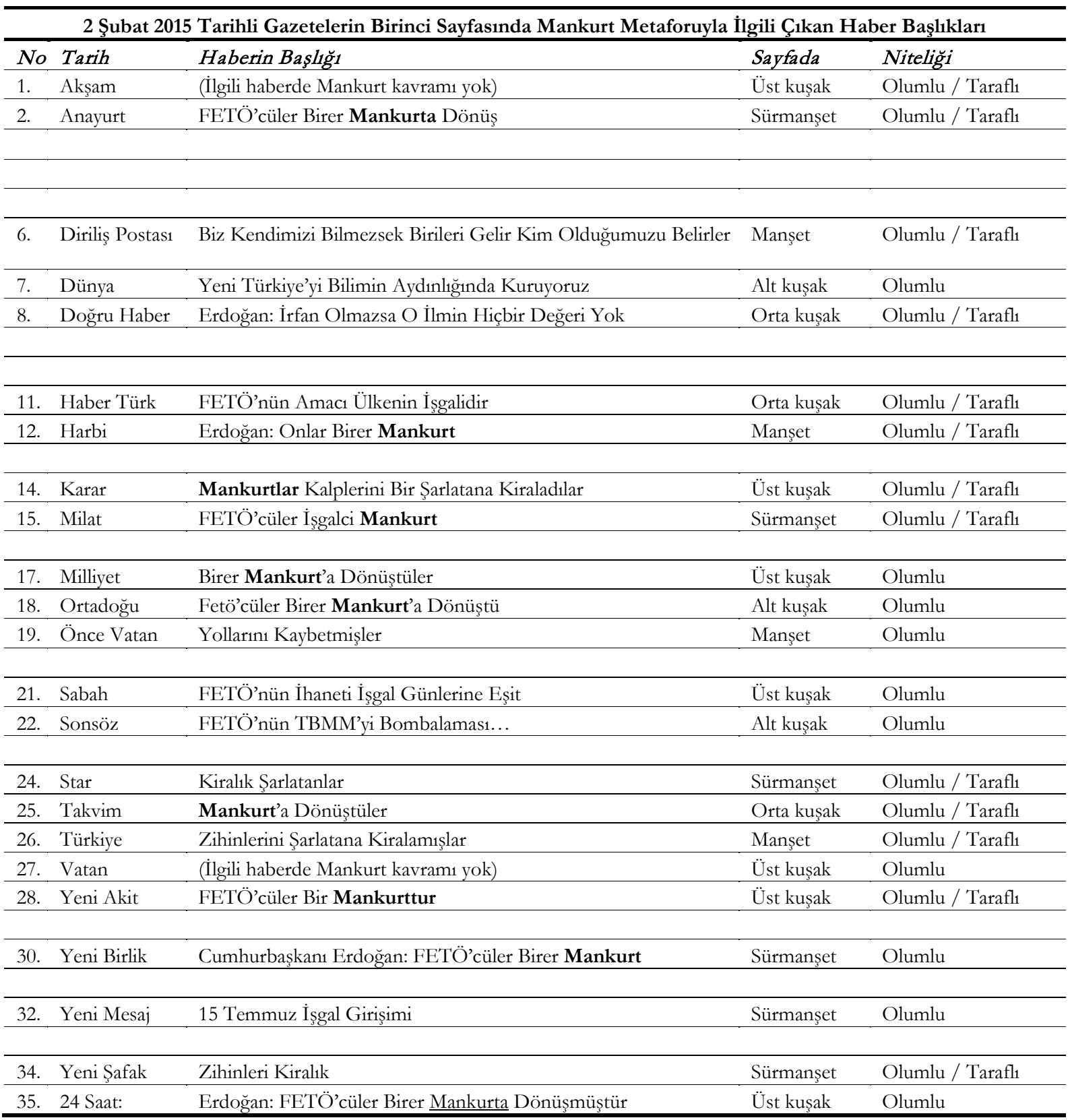


Erdoğan'ın Mankurt metaforunu kullanması yukarıdaki örneklerle sınırlı kalmamış, pek çok konuşmasında eleştirmek istediği kesimleri Mankurt olarak nitelendirmişidir. Kavramı halka açı konuşmalarında kullanmayı daha da sıklaştıran Erdoğan'ın ilerleyen süreçte de bu metaforu kullanacağı düşünülebilir. Erdoğan aktif bir siyasetçi ve siyasal pozisyonu itibariyle en önemli makamda bulunduğu için kamuoyu önünde söylediği her sözün, yaptığı her açıklamanın bir haber değeri bulunmaktadır. Basın ise haberlerinde öne çıarmak istediği konu ve kavramları kendi eşik bekçileri ile belirlemektedir. Erdoğan, 26 Mart 2017 tarihinde İstanbul Gaziosmanpaşa'da toplu açlış töreni ve miting programına katılmıs burada yaptığ1 konuşmanın bir yerinde "15 Temmuz gecesi darbe girişiminde bulunan FETÖ'cülerin ayıklanmasyla

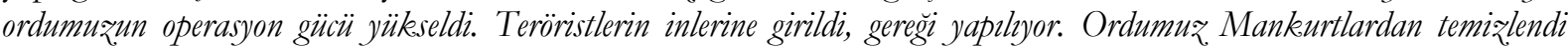
(Milliyet, 2017)." Ifadelerini kullanmıștır, fakat konuşmanın bu kısmı ertesi gün gazetelerin birinci sayfasına yansımamıştır. Erdoğan, 3 Nisan 2017 tarihinde Rize'de gerçekleştirilen toplu açıllş̧ töreninde konuşmuş burada vatandaşlara FETÖ'yü kastederek 'Böyle bir hainliği ancak aklimı, namusunu ve imanm Pensilvanya'daki o sarlatana bir dolara satmıs Mankurtlar yapabilir. Simdi çıkmıslar, utanmadan, sıkılmadan ișledikleri cinayetleri inkâr ediyorlar (Star, 2017).” şeklinde konuşmuş iki İslamcı muhafazakâr gazete Yeni Akit ve Milat gazeteleri bu konuşmada geçen Mankurt ifadesiyle birinci sayfalarına taşımıştır.

Görsel 5. Türk Ulusal Yąnlı Basınında Mankurt Metaforunun Gündeme Gelmesi

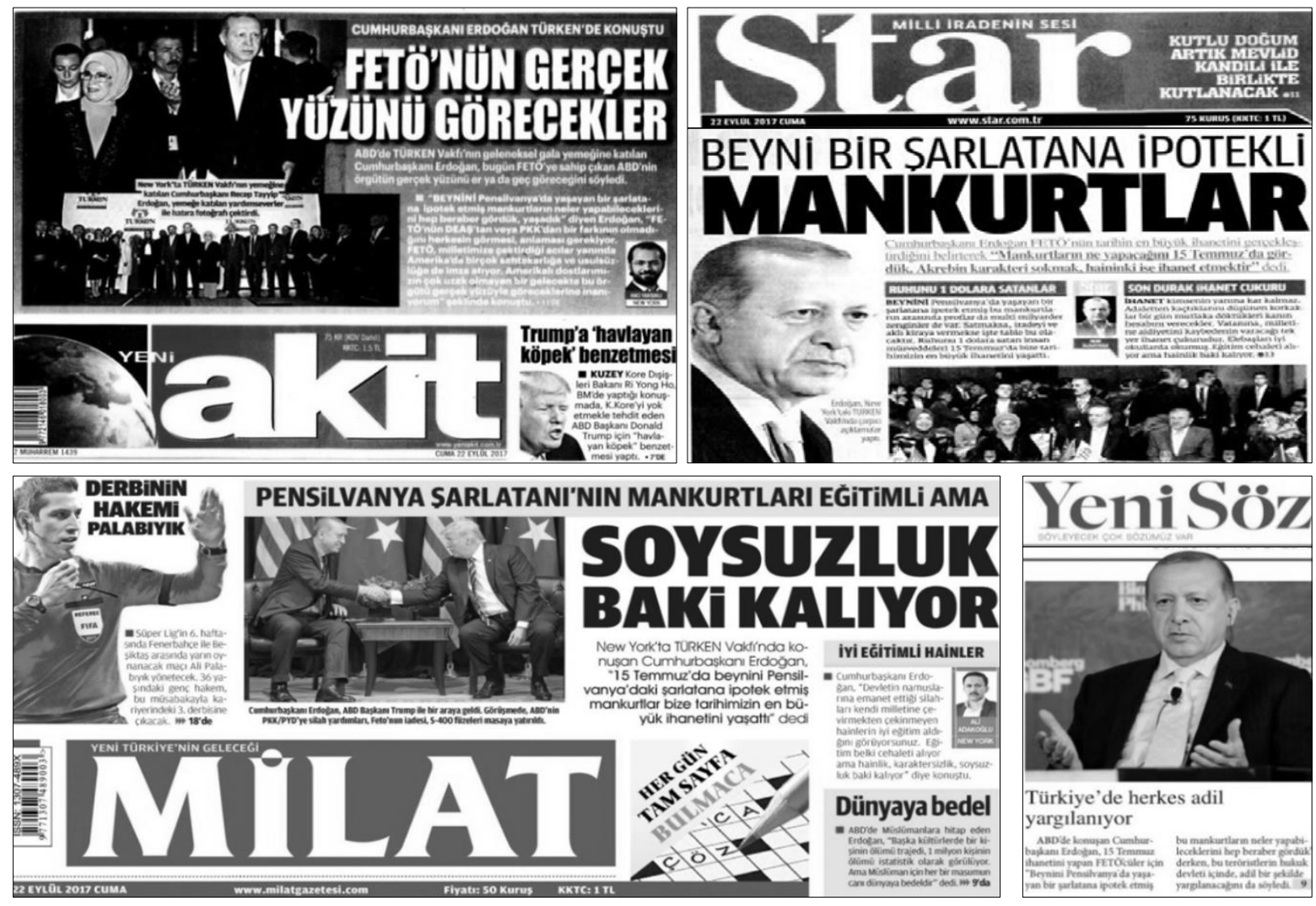

Erdoğan, 22 Eylül 2017 yılında ABD'de çeşitli temaslarında bulunmuş, burada bulunan TÜRKEN Vakfi'nın geleneksel gala yemeğine katılmış burada yaptığı konuşmanın bir bölümünde "Beynini Pensilvanya'da yaşayan bir șarlatana ipotek etmis bu Mankurtlarn neler yapabileceklerini hep beraber gördük. Bunlarm içinde proflar da var, bunlarn içinde multimilyarder zenginler de var ama bunlarn biçbiri kar etmiyor. Satmaksa, iradeyi ve akl kiraya vermekse verdig̈in andan itibaren işte tablo bu olacaktır. Rubunu 1 dolara satşsa çlkaran bu insan müsveddeleri 15 Temmuг, gecesi biže taribimiz̨in en büyük ibanetini yasattı (Star, 2017)." sözleri ile FETÖ’ye ağır eleștirilerde bulunmuștur. Erdoğan'ın bu eleștirilerinde kullandığı Mankurt metaforu Türk ulusal basının birinci sayfasında yoğun olmasa da yer almıştır (bakınız Görsel 5). Kavramı birinci sayfasına çıkaran gazetelerin genellikle muhafazakâr ve Ak Parti'nin siyasetine yakın olduğu bilinen gazeteler olması dikkat çekicidir. Bu gazetelerin neden bu kavrama ilgi duydukları ya da ana akım gazetelerinin mesela Hürriyet in kavramı kullanmaması veya çok az kullanması da ilgi çekici bir durum olarak görülebilir. 
Görsel 6. Türk Ulusal Yą̧lı Basinnda Mankurt Metaforunun Gündeme Gelmesi
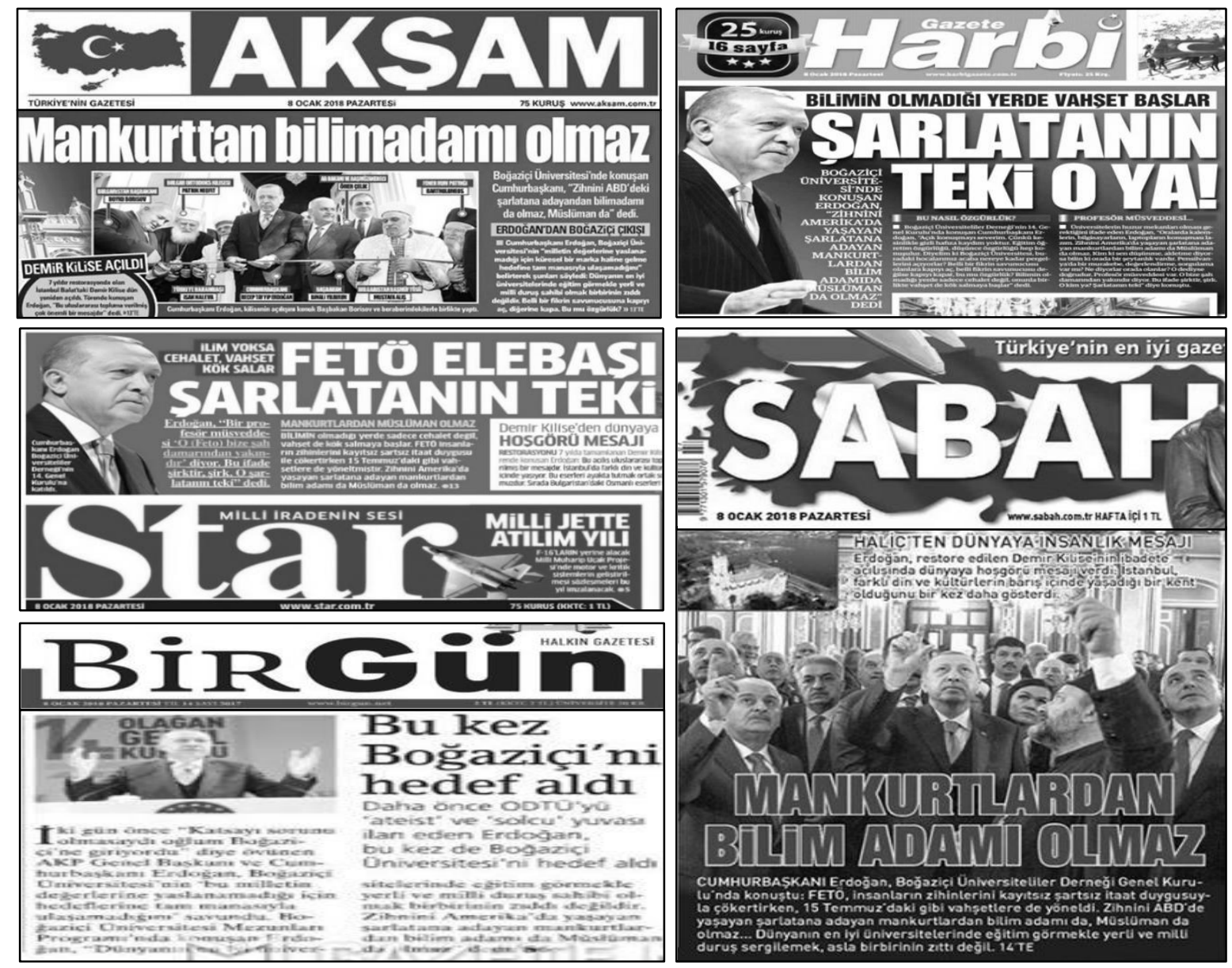

$\mathrm{Bu}$ çalışma için Türk ulusal basını taranmış, Mankurt metaforunu gazetelerin nasıl vurguladıkları, kavrama yönelik ilgileri çözümlenmeye çalışılmıştır. Çalışma içinde görülmüştür ki cumhurbaşkanının bu metaforu kullanma sıklğı arttıkça basının Mankurt metaforunu kullanamaya yönelik ilgisi azalmış, gazeteler ana sayfasına veya haberin başlı̆̆ına bu kavramı koymama eğilimi göstermişlerdir. Kavrama ilgi gösterenler genel olarak aynı gruba, ya da aynı siyasal görüşe yakın gazeteler olmuştur Görsel 6'da görüldüğü gibi. Erdoğan, 7 Ocak 2018 tarihinde Boğaziçi Üniversitesi mezunları programında konuşmuş, burada hem üniversite yönetimini eleştirmiş, hem de FETÖ'ye vurgu yaparak 'Ülkesine, milletine ve insanhlğa hizmet etmek yerine zihnini ve yüreğini Amerika'da yaşayan bir şarlatana adayan Mankurtlardan bilim adamı da olmaそ: Müslüman da olmaz. (Hürriyet, 2017)." demiştir. Elbette cumhurbaşkanın konuşmasının haber değeri açısından önemi tartışılmaz fakat Görsel 6'da görüldüğü üzere Bir Gün gazetesi dışında Erdoğan'ın konuşmasında ifade ettiği Mankurt metaforuna yandaş oldukları iddia edilen gazetelerden başka vurgu yapan başka yayın olmamıştır. Bir Gün gazetesi de kavrama yer vermiştir fakat Erdoğan perspektifinden olumlu bir başlık kullanmamış, hem hükümete hem de FETÖ'ye eleştirel yaklaşmıştır. Gazete, başlıkta Erdoğan'ı hedef alırken haberin devamında Erdoğan'a dayandırdığı söylemle FETÖ’yü eleştirmiştir.

Şöyle bir durumu da göz ardı etmemek gerekir: Erdoğan gün içerisinde birden fazla programa katıldığı için gazeteler kendi yayın politikalarına uygun görece en önemli konuyu birinci sayfaya taşıdıkları için dolayısıyla ana akım medyanın bu durumdan kaynaklı Mankurt metaforunu ön plana çıkarmamış olmaması da düşünülebilir. Örneğin 8 Ocak 2018 tarihli neredeyse tüm ulusal gazeteler Erdoğan'nn Demir Kilise'nin açılışına katılmasını birinci sıra haberi yani manşet olarak vermiştir.

Erdoğan, 28 Ocak 2018 tarihinde partisinin Amasya il kongresine katılmıs, burada Türk ordusunun sınır ötesi Afrin harekâtıyla ilgili değerlendirmelerde bulunmuştur. Erdoğan, bu değerlendirmeleri yaparken TSK'nın sınır ötesi harekâtına "savaşa hayır diyoruz" kampanyasıyla karșı çıkan Türk Tabipler Birliğ̣’’ni (TTB) ağır bir dille eleştirmiştir. Erdoğan kongrede yaptığ1 konuşmada TTB'yi hedef alarak "Terör örgütü ögretmenleri okul önlerinde, anneleri sokak ortasında, babalar evlatlarn gǫ̈ü̈ önünde, polisleri uyuduklar yataklarnnda, kaymakamımı̨ı masasmm altma koyduklar bomba ile odasinda, Yasin Börïleri kıstırdıklar binada, binlerce masumu en savunmasz , hallerinde katlederken bunlardan tek bir ses duydunuz mu? Sözde tabipler birliği 'savasa hayır' diyor. Senin 
her yerin tabip olsa ne yazar. Sözde profesör. Senin her yerin profesör olsa ne yazar? Bunlar aydin falan değil, Mankurt sürüsüdür. Bunlar 'savaşa hayır' diyerek aslinda zulme 'evet' diyorlar. Asıl kirlilik budur. Amasya'dan Türk milleti adina bu güruha, topunuza da hayır diyoruz. T⿰рек daha önce benzer girişimleri yapanlar olduğu gibi bunlar da millet ve devlet olarak hafızalarımıza kaydediyoruz. (Vatan 2018).” Bakınız görsel 7'de Erdoğan'ın T'TB'nin dağıtmış olduğu "savaşa hayır" bildirisine imza atanları Mankurtlar sürüsü olarak eleştirdiği sözlerine birinci sayfasında ye veren gazeteler aşağıda görülmektedir. Üç büyük medya grubunun gazetelerinin birinci sayfa haberinde Erdoğan’ın kullandığı Mankurt metaforu Görsel 7’deki gibi verilmiştir.

Görsel 7. Türk Ulusal Yąulı Basininda Mankurt Metaforunun Gündeme Gelmesi
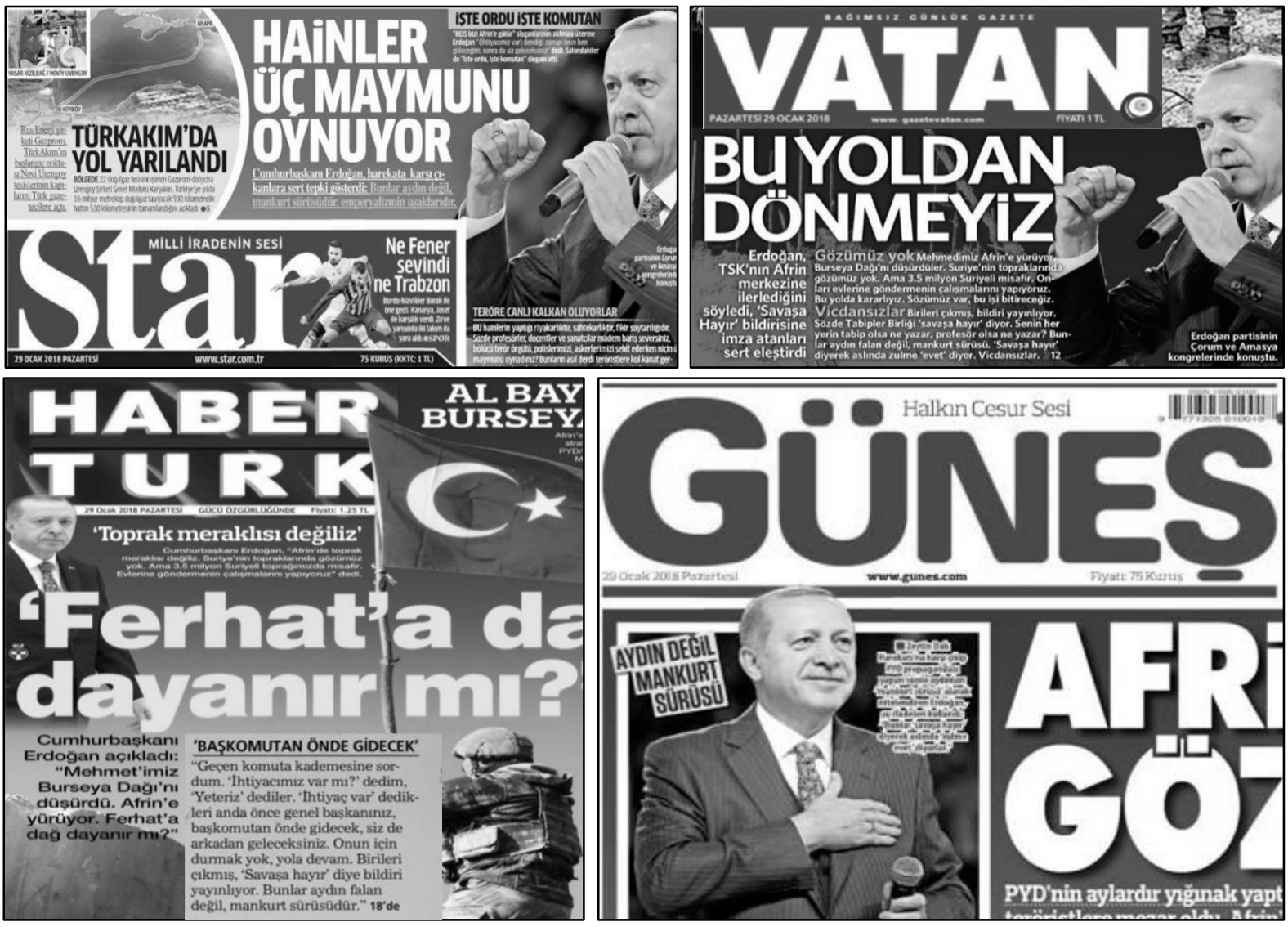

Erdoğan, farklı kesimleri kamuoyu önünde eleştirmek maksadıyla Mankurt metaforunu kullanması 2018 yılında artarak devam etmiştir. Erdoğan, 3 Nisan 2018 tarihinde İstanbul'da yapımı tamamlanan tesislerin açlış töreninde konuşma yapmış, burada CHP milletvekili Haluk Pekşen'in 'Türkije'de biç

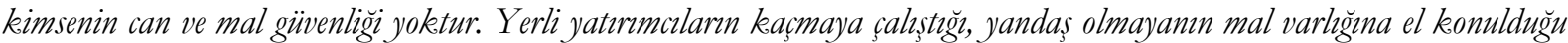
bukuk güvenliği olmayan bir ülkeye yatırm yapacaklar sıraya girsin (Akşam, 2018).” şeklinde attığ1 bu tweeti sert sözlerle eleştirmiştir. Pekşen'e "Geçtiğimiz günlerde milletvekili sıfatı taşıyan bir tanesi, biz̧im uluslararası yatrrmalar ülkemize davet etmemize Türkiye'de kimsenin can ve mal güvenliği yok diye mesajla cevap vermis. Bu tam bir kötü örnektir. Biz. bunlara Mankurt diyoruz: Mankurt beyni iğdis edildiği için kendi toplumunu, kendi halkem, hatta kendi ailesini düsman gören, onlara saldiran kiși demektir. Her terörist bir Mankurttur. Ülkesinin ve milletinin aleybine çalısanlar da birer Mankurttur (Hürriyet, 2018)" ifadelerini kullanmıştır. Bu ifadeler ulusal basının birinci sayfasına çok fazla yansımamıştır. Sadece üç gazete kavramı birinci sayfasından vermeyi tercih etmiştir. Diğer gazeteler Erdoğan’ın konuşmasındaki farklı konu başlıklarını birinci sayfasına taşırken Karar, Star ve Dirilis Postası kavrama birinci sayfalarında yer vermişlerdir (bakınız Görsel 8). Yukarıda da izah edildiği üzere kavrama muhafazakâr ve iktidara yakın olduğu iddia edilen gazeteler en fazla yer verirken, muhalif basın kavrama daha az yer vermiş, bazıları hiç yer vermemiştir. 
Görsel 8. Türk Ulusal Yaẓll Basinnda Mankurt Metaforunun Gündeme Gelmesi
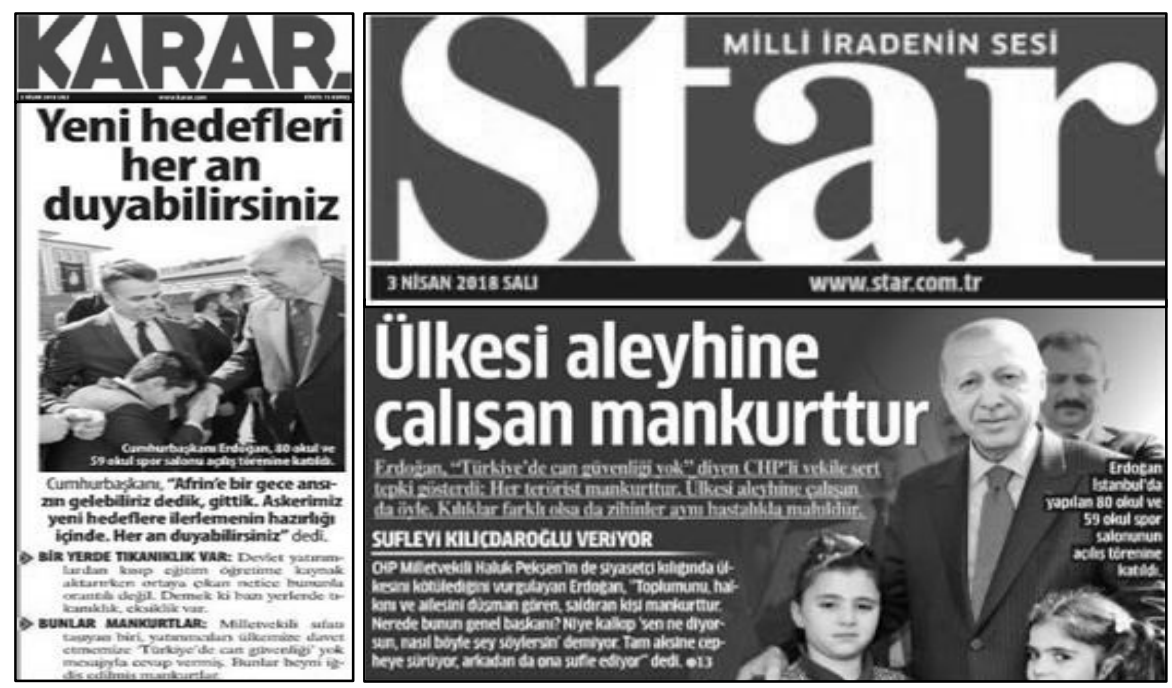

\section{DíRÍLiş POSTASI}

\section{HER TERÓRIST}

MANKIRTTLR

Endoban, tuluslararas yatrimeya bia ber loutii yalanla "Tinkige'ye gecimcyin" mesej veren CiP Trabton Milletwedili Haluk Peksen'ies gecrnodi. Türige dismans Pclich icia "Terúrist mankuntur" icphisini koyen Endoban, Türojyc karyilanma Akkyy Nableer Suniralt ile cevap verihocefinin altam sized, "Bu tam bis Löth ónchir. Bunlara cevalu Menin'de Alkws Niklect Santra. linis tenel atras tereniyle vereceplo. Ifte bunlar mankurttur. Her terobrist bir mankurtur" "dodi. SAYTA + POLITIKA

Erdoğan 2018 yılı içinde farklı tarihlerde yaptığı kamuya açık konuşmalarında Mankurt metaforunu 6 kez kullanmış, son 3 konuşmasında kullandığı bu metafor ulusal basının birinci sayfasında yansımamıştır.

Tablo 4. Erdoğan'in Mankurt Metaforunu Kullanmasmmn Gazetelerin Birinci Sayfasina Kronolojik Olarak Yansiması

\begin{tabular}{|c|c|c|c|c|}
\hline \multicolumn{2}{|c|}{ Ne zaman } & \multirow{2}{*}{$\begin{array}{l}\text { Nerede } \\
\text { İstanbul/Yenikapı'da teröre lanet mitinginde }\end{array}$} & \multirow{2}{*}{$\begin{array}{l}\text { Kimler için } \\
\begin{array}{l}\text { HDP, PKK ve diğer terör örgütleri } \\
\text { için }\end{array}\end{array}$} & \multirow{2}{*}{$\frac{\text { Ne Kadar }}{3 \text { gazetede (1.sayfada) }}$} \\
\hline 1 & 21.09 .2015 & & & \\
\hline 2 & 20.10 .2015 & Ankara, Beştepe'de muhtarlar toplantısında & Akademisyenler, yazarlar "aydınlar" & 15 gazetede (1.sayfada) \\
\hline 3 & 02.02 .2017 & Ankara, Beștepe'de TÜBA ödül töreninde & FETÖ için kullanmıştır & 16 gazetede (1.sayfada) \\
\hline 4 & 26.03 .2017 & İstanbul/Gaziosmanpaşa'da toplu açllsşta & FETÖ için kullanmıştır & 1.sayfada yer almamıştır \\
\hline 5 & 03.04 .2017 & Rize'de toplu açılış töreninde & FETÖ için kullanmıştır & 2 gazetede (1.sayfada) \\
\hline 6 & 22.09 .2017 & ABD/TÜRKEN Vakfi yemeğinde & FETÖ için kullanmıştır & 4 gazetede (1. sayfada) \\
\hline 7 & 07.01.2018 & İstanbul/Boğaziçi Üniversitesinde & FETÖ için kullanmıştır & 5 gazetede (1. sayfada) \\
\hline 8 & 28.01.2018 & Amasya'da Ak Parti il kongresinde & Türk Tabipler Birliği (TTB) & 4 gazetede (1. sayfada) \\
\hline 9 & 03.04 .2018 & İstanbul/ Başakşehir'de toplu açıllş̧ta & CHP’li vekil Haluk Pekşen için & 3 gazetede (1. sayfada) \\
\hline 10 & 14.05.2018 & $\begin{array}{l}\text { İngiltere/Londra Türk } \\
\text { toplantıda }\end{array}$ & Akademisyenler, yazarlar "aydınlar" & 1.sayfada yer almamıştır \\
\hline & 04.06 .2018 & Diyarbakır'da iftar programında & $\begin{array}{l}\text { Aydın, sanatçı, gazeteci, siyasetçi, } \\
\text { akademisyenler }\end{array}$ & 1.sayfada yer almamıştır \\
\hline 12 & 14.08 .2018 & Ankara/SETA'da Ak Parti konferansinda & $\begin{array}{l}\text { Gençleri yurt dişında çalışmaya } \\
\text { teşvik edenler için }\end{array}$ & 1.sayfada yer almam \\
\hline
\end{tabular}

Tablo 4 incelendiğinde Erdoğan 2015’ten 2018 yllına kadar yaklaşık 4 yıldır Mankurt kavramını kullanmaktadır. Kavramı ilk olarak 20 Eylül 2015 yllında terör örgütü PKK ve onu desteklediğini iddia ettiği HDP ve yöneticileri için kullanmıştır. Sonraki dönemlerde ise başta FETÖ olmak üzere diğer daha marjinal muhalefet yapan toplum kesimleri için de bu metaforu kullandığ1 görülmüsstür. Tablo analiz edildiğinde Erdoğan 5 defa FETÖ ve taraftarları için Mankurt derken, 4 defa da doğrudan ve dolaylı olarak PKK'ya destek mahiyeti taşıyan açıklamalarından dolayı çeşitli kesimlere bu benzetmeyi yapmıştır.

\section{Tartı̧̧ma, Sonuç ve Öneriler}

Kırgız yazar Cengiz Aytmatov'un Nayman Ana söylencesi ile ortaya çıkardığı Mankurt, Mankurtizm kavramlarının Türkiye Cumhuriyeti Cumhurbaşkanı Recep Tayyip Erdoğan tarafindan kullanılması sonucu kavramın ulusal basında gündem olması bu çalışmada sistematik şekilde ele alınarak kavramın kullanıldığı bağlam analiz edilmeye çalışılmıştır.

Kavram, Tablo 4'de görüldüğü üzere farklı zaman ve mekânlarda Erdoğan tarafindan kamuoyu gündemine getirilmiştir. Kavramın gündeme gelişi ve kullanıldığı bağlam daha çok ihanetle özdeştirilmiştir. 
Yani Türkiye'nin içerisinden çıkıp, sonrasında yerli ve yabancı işbirlikçilerden aldıkları destekle terörist faaliyetlerde bulunan hain kesimlere yönelik bir eleştiri argümanı olmuştur. Ayrıca Erdoğan'ın söylemlerinden hareketle bazı siyasal ve sosyal olayları nitelemek için bir metafor olarak kullanıldığı da bu çalışmada dikkati çekmiştir.

Erdoğan tarafindan ilk kez Eylül 2015 tarihinde kullanıldığında yazılı basın kavrama çok fazla dikkat çekmemiştir. Erdoğan'ın Mankurt metaforunu ikinci ve üçüncü kez kullanması Türk yazılı basının birinci gündemi olmuş, manşet ve sürmanşetlere taşınmıştır. Erdoğan, terörle mücadele ederken teröristlere ve teröristleri destekler mahiyette açıklamalar yapan kesimlere bu kavramla yüklenmiş, Mankurt metaforunun hedefine muhtelif kesimlerden insanı koymuştur. Erdoğan tarafından değişik dönemlerde sıkça tekrarlanan kavram ilk kullanıldığı dönemler kadar ulusal basının dikkatini çekmemiştir.

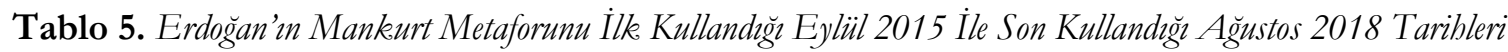
Arasinda Ulusal Gazetelerin Birinci Sayfasinda Nasil Yer Aldiğmmn Değerlendirilmesi

\begin{tabular}{|c|c|c|c|c|c|c|c|c|c|c|c|c|c|}
\hline \multicolumn{2}{|c|}{ Ne zaman } & \multicolumn{2}{|c|}{ Nerede } & \multicolumn{3}{|c|}{ Nas1l } & \multicolumn{5}{|c|}{ Niteliği } & \multicolumn{2}{|c|}{ Ne kadar } \\
\hline 胥 & & 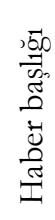 & 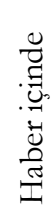 & 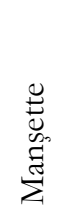 & 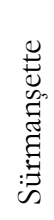 & 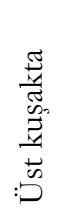 & 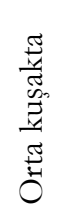 & 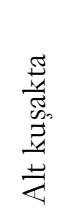 & $\frac{\vec{\Xi}}{\Xi_{\Xi}^{\prime}}$ & 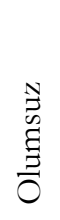 & $\begin{array}{l}: \\
: 0 \\
Z\end{array}$ & 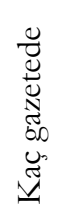 & 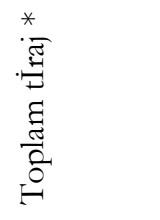 \\
\hline 1 & 21.09.2015 & & 3 & & 2 & & & & 3 & & & 3 & 465.791 \\
\hline 2 & 20.10 .2015 & 10 & 5 & 6 & & 3 & 3 & 2 & 12 & 2 & 1 & 15 & 2.142.085 \\
\hline 3 & 02.02 .2017 & 10 & 6 & 4 & 5 & 3 & 3 & 1 & 16 & & & 16 & 1.341.548 \\
\hline 4 & 26.03 .2017 & \multicolumn{12}{|c|}{ Yazılı Basının Birinci Sayfasına Yansımamıştır. } \\
\hline 5 & 03.04 .2017 & & 2 & 1 & 1 & & & & & & & 2 & 105.000 \\
\hline 6 & 22.09 .2017 & 2 & 2 & 1 & 2 & 1 & & & 4 & & & 4 & 163.755 \\
\hline 7 & 07.01.2018 & 2 & 3 & 1 & 1 & & 2 & 1 & 4 & 1 & & 5 & 570.087 \\
\hline 8 & 29.01 .2018 & 1 & 3 & 1 & 1 & 1 & 1 & & 4 & & & 4 & 516.204 \\
\hline 9 & 03.04.2018 & 1 & 2 & 1 & 1 & 1 & & & 3 & & & 3 & 209.262 \\
\hline 10 & 14.05 .2018 & \multicolumn{12}{|c|}{ Yazılı Basının Birinci Sayfasına Yansımamıștır. } \\
\hline 11 & 04.06 .2018 & \multicolumn{12}{|c|}{ Yazılı Basının Birinci Sayfasına Yansımamıstır. } \\
\hline 12 & 14.08.2018 & \multicolumn{12}{|c|}{ Yazılı Basının Birinci Sayfasına Yansımamıştır. } \\
\hline To & lam & 26 & 26 & 14 & 13 & 9 & 9 & 4 & & & & 52 & 5.513 .732 \\
\hline
\end{tabular}

*Tirajlar aynı tarihlerde http://www.medyatava.com/tiraj_sayfasından alınmıştır.

Tablo 6'da Ak Parti iktidarları döneminde yayın hayatında olan gazeteler görülmektedir. Ulusal yayın yapan bu gazetelerin bazılarının marka tarihi bir asrı aşarken (Yeni Asır gibi) bazıları henüz birkaç yıl önce yayın hayatına başlamış gazetelerdir. Bazı gazeteler süreç içinde kendini tasfiye etmiş (Vahdet, Yeni Yǚsynl gibi) bazıları da kanunla kapatılmıştır (FETÖ ve bölücü örgüte destek verenler). Ulusal yayın yapan gazeteleri hükümete yakın olanlar, yayınlarıyla hükümete muhalif olanlar ve ortada olanlar şeklinde genel olarak üç kategoriye ayırmak mümkündür. Ulusal gazeteler bu kategorik sınıflandırmanın dışında kendi aralarında da birçok guruba ayrılmaktadır. Mesela: hem İslamcı muhafazakar olup muhalif olanlar (Milli Gazete, Yeni Asya, Yeni Mesaj) ile İslamcı ve iktidara taraflı yayın yapanlar (Yeni Akit, Diriliş Postası, Doğru Haber, Milat vb.) ya da muhalif olup kendi içinde gruplara ayrılmışlardır; fikir gazeteleri, doğrudan siyasi propaganda yapanlar, seküler, ulusalcı (S̈̈zçi), lümpen (Korkusu») veya liberal, liberal sol (Cumburiyet) gazetecilik yapanlar gibi sınıflandırmak mümkündür. Adına zaman zaman holding gazeteciliği de denen merkez medya veya ana akım gazeteler şeklinde anılan ve yayınları ile ortada durmaya çalışan, bazen iktidara yakın bazen de muhalefete yakın yayınları olan gazeteleri de (Hürriyet, Milliyet ve Habertürk) üçüncü kategoride değerlendirmek mümkündür?

\footnotetext{
${ }^{7}$ Ulusal medyanın en büyük gurubu olan Doğan Grubunun el değiştirmesi bu yaygın kanaati değiştirmiştir.
} 
Tablo 6. Ulusal Gazetelerin Mankurt Metaforuna Birinci Sayfasinda Yer Verme Durumu

\begin{tabular}{|c|c|c|c|c|c|c|c|}
\hline \multicolumn{8}{|c|}{ Mankurt Metaforuna En Fazla, En Az ve Hiç Yer Yer Vermeyen Gazeteler } \\
\hline En fazla & Adet & En $a z$ & Adet & Hiç yer vermeyenler & 2 Adet & Adet & Toplam \\
\hline Star & 5 & Aydınlık & 1 & Milli Gazete & Akşam & 2 & \\
\hline Sabah & 4 & Anayurt & 1 & Posta & Bir Gün & 2 & \\
\hline Milat & 4 & Cumhuriyet & 1 & Yeni Asya & Diriliş Postas1 & 2 & \\
\hline Yeni Akit & 3 & Hürriyet & 1 & & Güneş & 2 & \\
\hline \multirow[t]{15}{*}{ Haber Türk } & 3 & Sözcü & 1 & Yeni Mesaj & Harbi & 2 & \\
\hline & & Ortadoğu & 1 & Yurt & Karar & 2 & \\
\hline & & Yeni Birlik & 1 & Evrensel & Milliyet & 2 & \\
\hline & & 24 Saat & 1 & & Takvim & 2 & \\
\hline & & & & & Türkiye & 2 & \\
\hline & & & & & Vatan & 2 & \\
\hline & & & & & Yeni Söz & 2 & \\
\hline & & & & & Yeni Şafak & 2 & \\
\hline & & & & Vahdet & & & \\
\hline & & & & Özgür Gündem & & & \\
\hline & & & & Yeni Yaşam & & & \\
\hline & & & & Korkusuz & & & \\
\hline & & & & Doğru Haber & & & \\
\hline & & & & İstiklal & & & \\
\hline & 19 & & 9 & 0 & & 24 & 52 \\
\hline
\end{tabular}

Kaynak: Abdullah Köktürk, 2018

Yukarnda yer alan Tablo 5 ve Tablo 6 birlikte değerlendirildiğinde; Erdoğan'ın Mankurt metaforunu ilk olarak Türkiye gündemine soktuğu tarih olan 21 Eylül 2015 tarihinden bu çalısmanın yapıldığı 1 Eylül 2018 tarihine kadarki 3 yllık süreyi kapsayan Türk ulusal basını taranmış, kavrama kaç gazetede, hangi kuşakta ve hangi nitelikte yer verildiği, kaçında kavram haberin başlığında kaçında haberin içinde olduğu araştırılmıştır. Ayrıca kavramı birinci sayfasına taşıyan gazetelerin o dönemki baskı sayıları da tespit edilerek kavramın ulaştığı hedef kitleler (okurların sayısı) anlaşılmaya çalışılmıştır.

Tablo 5 incelendiğinde Mankurt kavramının Türk ulusal basınında 12 farklı tarihte, 3 farklı yllda toplam 52 defa gazetelerin birinci sayfasında gündeme geldiği görülmüştür. Kavrama, 26 haberin başlı̆̆ında, 26 haberin de içerisinde yer verilmiştir. Üç yıl içerisinde ulusal yayın yapan muhtelif gazetenin birinci sayfasında toplam 52 defa yer alan Mankurt kavramı 5 buçuk milyonu aşan baskıyla okurla buluşmuştur. Elbette bir gazeteyi birden çok kişinin okuduğu etki alanıyla çarpılırsa bu rakam belki iki üç katını da aşabilir. Mankurt metaforunu sayfalarına taşıyan gazeteler genel olarak hükümetin ve Erdoğan'ın politikalarını benimseyen ve destekleyen gazetelerdir. Mesela en fazla yer veren Star gazetesi 5 kez, Sabah ve Milat ise 4 kez kavrama yer vermiştir (bakınız Tablo 6). Yani hükümetin politikalarını benimsemeyen muhalif gazeteler kavramı görmezden gelmiştir. Bu itibarla Erdoğan'ın politikalarını destekleyen gazeteler genelde kavramın geçtiği haberi üst kuşaklardan hatta manşetten verirken, ana akım medya ise bazen üst kuşaktan bazen de alt kuşaktan vermeyi tercih etmiştir. Hükümete muhalif yayın politikalarını benimseyen gazeteler (Cumburiyet, Bir Gün) ise genelde kavramın geçtiği ilgi haberi alt kuşaktan vermeyi tercih etmiştir. Hükümetin politikalarına taraf olmayıp kavramın geçtiği ilgi haberi tek bir kez yayınlayan ve üst kuşaktan veren (Sözcii) istisna muhalif gazete de olmuştur.

Kavramı birinci sayfasına taşıyan gazeteler, kavramı kullanan kişiye yani Erdoğan’a göre kavrama nitelik kazandırmışlardır. Mankurt metaforunu kullanan açısından olumlu, olumsuz veya nötr yaklaşımlarda bulunmuşlardır. Kavramı sadece iki kere birinci sayfasında kullanan Bir Gün gazetesi ve bir sefer kullanan Cumburiyet gazetesi "Erdoğan ülkenin, aydın, fikir sahibi kişilerini düşünemeyen, cahil hatta robotlaştırılmış insanlar olduğunu söyleyerek onlara hakaret ediyor, asıl kendisi Mankurttur" imasını uyandıracak şekilde vermişlerdir (Tablo 5).

Tablo 5 incelendiğinde dikkati çeken başka bir konu ise Erdoğan'ın Mankurt metaforunu her geçen zaman daha sıklıkla kullandığıdır. Erdoğan, 2015 yılında kavramı kamuoyu önünde iki kez kullanmıştır. Erdoğan'ın 2016 yllında kamuoyuna yansıyan konuşmalarında Mankurt metaforunu kullandığ1 
görülmemektedir. Erdoğan 2017 yılında ise 4 defa, 2018 yılının ilk dokuz ayında ise tam 6 kez kullanmıştır. Tablo 5'de dikkat çeken başka bir şey ise Mankurt metaforu kullanıldığı ilk dönemlerde ulusal basında geniş yer bulurken sonraki dönemlerde kavrama ulusal basının ilgisinin azalmasıdır. Bu durumun basın için "habercilik, haberde öncelik" gibi kendi içinde haklı sebepleri vardır. Mesela 2018 Haziranda Diyarbakır'da seçim mitingi yapan Erdoğan akabinde kanaat önderleri ile iftarda bir araya gelmiş buradaki konuşmasında kavramı kullanmıştır. Doğal olarak gazeteler mitingde konuşulanları birinci sayfalarına taşırken kanaat önderleri ile yapılan iftar yemeği ön plana çıkmamıştır. Ya da yine 2018 Haziranında İngiltere temaslarında çok yoğun bir program esnasında Türk öğrencilerle yaptığ 1 toplantıda Mankurt metaforunu kullanmıştır fakat gündemde ABD'nin İsrail elçiliğini Kudüs'e taşıması, İsrail'in Filistin'i bombalaması ve çok sayıda sivilin hayatını kaybetmesi gibi gündemin daha öne çıan konuları olduğu için Erdoğan'ın öğrencilerle buluşmasında kullandığı kavram gazetelerin birinci sayfasına yansımamıştır. Yine aynı şekilde 14 Ağustos 2018 tarihinde Erdoğan'in SETA'da yaptığ1 konuşmada kavrama vurgu yapması gazetelerin birinci sayfasına yansımamıştır çünkü o sırada ABD'nin Türkiye üzerine açıktan bir ekonomik savaş açması ve buna bağlı konular gazetelerin öncelikli gündemi olmuş, bu sebepten Mankut metaforu geri planda kalmıştır.

Çalışmada ilginç bir nokta dikkati çekmiştir; Erdoğan'ın kullandığı kavramı bazı gazeteler yayınlarında 1srarla kullanmazken bazı gazeteler de özellikle kavrama vurgu yapamaya özen göstermişledir. Tablo 6'da görüldüğü üzere Erdoğan'ın Mankurt metaforuna muhatap olduğu varsayılan FETÖ medyası ile sol zemine ve İslamc1/milliyetçi muhalif düşünceye daha yakın duran gazeteler kavramı kullanmaktan kaçarken, hükümetin politikalarına daha yakın duran gazeteler sıklıkla birinci sayfa haberlerinde metafora yer vermişlerdir. Cumburiyet ve Bir Gün gibi sol fikriyattaki neşriyat zaman zaman Mankurt kavramına yer vermişse de bu kullanımları istihza-i bir amaç taşımıştır. Yani kavramı Erdoğan’ı eleştirmek amaçlı kullanmışlardır. Ana akım gazeteler ise orta düzeyde ve genelde olumlu nitelikte kavramı birinci sayfalarına taşımışlardır.

\section{Etik Beyan}

"Siyasal ve Sosyal Bağlamda Mankurt Kavramının Türk Yazılı Basınında Metaforik Kullanımı” başlıklı çalısmanın yazım sürecinde bilimsel, etik ve alıntı kurallarına uyulmuş; toplanan veriler üzerinde herhangi bir tahrifat yapılmamış ve bu çalışma herhangi başka bir akademik yayın ortamına değerlendirme için gönderilmemiştir.

\section{Kaynakça}

Aytmatov, C. ve Şahanov, M. (2000). Kuz başındaki avcının çı̆̆lğ̆. Ankara: Tolkun Yayınları.

Aytmatov, C. (1991). Gün olur asra bedel (Çev: R. Özdek). İstanbul: Ötüken Yayınevi.

Azap, S. (2017). Közkamanlık: İhanet ve kimlik sorunsalı. Akademik Sosyal Araștırmalar Dergisi, 58(41), 104-117.

Bayram, Y. (2015). Medya-siyaset gündemi ilişkisi kapsamında türkiye’de ulusa sesleniş konuşmalarının gündem belirleme gücü. Tarih Okulu Dergisi, 8(XXIV), 405-438.

Çınar, İ. (2012). Neden ve nasıl mankurtlaştırllyoru₹. İstanbul: IQ Kültür Sanat Yayıncıllk.

Gencer, Z. T. (2012). Medyanın gündem olusturma sürecinde sosyal entropinin rolü üzerine uygulamal bir çalısma (Doktora Tezi). Selçuk Üniversitesi Sosyal Bilimler Enstitüsü, Konya.

Gökçe, O. (2006). İçerik analizi kuramsal ve pratik bilgiler. Ankara: Siyasal Kitabevi.

Güz, N. (1996). Türk basını’nda gündem oluşturma. Yeni Türkiye Dergisi, Medya Özel Sayısı 12, 982-983.

Kizıltepe. N. G. (2008). Aytmatov demek olan cümle. Anlayıs, 62. http:/ / www.anlayis.net/makaleGoster.aspx?dergiid=62\&makaleid=1389

Kolcu, A. İ. (1989). Milli romantik duyuş tarz1 ve Cengiz Aytmatov'da milliyet unsurları II. Ayane, 2(22), 2.

Kolcu, A. İ. (2002). Bozkırdaki bilge: Cengiz Aytmatov. Ankara: Akçă̆ Yayınları.

Kulamshaeva, B., (2008). Kırgız bikâye ve destanlarnda anlatı zamanlar (Doktora Tezi). Ankara Üniversitesi Sosyal Bilimler Enstitüsü, Ankara.

Tavşancıl, E. ve Aslan, E. (2001). İçerik analiz̧i ve uygulama örnekleri. İstanbul: Epsilon Yayıncılık.

Yıldırım, K. (2015). Bozkermn yitik çocuklar juan-juan’lar. İstanbul: Yeditepe Yayınevi.

Yilmaz, B. D. (2015). Cengiz. Aytmatov kitabı. Ankara: Atlas Yayınları.

Yüksel, E. (2001). Medyanın gündem belirleme gücü. Konya: Çizgi Kitabevi.

Yüksel, E. Ed. (2009). Sibirli aynanın sirları. Eskişehir: Anadolu Üniversitesi Yayınları.

Zant, N. (1983). Cengiz, Aytmatov Paris’te (Söyleşi, Çev: S. Büyükdağ). Kardaş Edebiyatlar, 6. 


\section{EXTENDED ABSTRACT}

In this study, the "Mankurt" metaphor used in Chingiz Aitmatov's "Gün Olur Asra Bedel" book was examined. The study focused on how the concept was reflected in the Turkish national press and how it came to the agenda. In 2008, Chingiz Aitmatov went to Kazan, the capital of the Autonomous Republic of Tatarstan, and participated in the transfer of the novel Gün Olur Asra Bedel to the cinema. He fell ill during the filming and was taken to Germany's Nünberg for treatment and died there. According to UNESCO records, Aitmatov is a world famous Kyrgyz Soviet writer whose works have been translated into 176 languages. The international recognition of Aitmatov was made possible by writing his books in the widely used Russian language. Aitmatov was considered the author of Soviet or Russian literature, since he wrote in Russian by some critics and colleagues.

TÜRKSOY, which is accepted as UNESCO of the Turkish World, declared 2018 as the year of Chingiz Aitmatov. The most well-known feature of the author is that he blends Kyrgyz oral literature and myths in Kyrgyz folklore with universal values and reflects them on his works. When Gün Olur Asra Bedel published her novel, she had strong reflections in the world public opinion. In particular, he drew attention to the concepts he used and his messages about these concepts. In this study, the historical context of the concept of Mankurt, the date of its emergence and the messages given by the author with this metaphor are emphasized. In this study, how the concept of "Mankurt" affects Turkish political life and how the central media handled this concept was also examined. The study is based on the agendasetting theory of mass communication theories. As the method of the research, the first pages of the Turkish national press were subjected to content analysis. Content analysis is a frequently used method in text analysis. Using this method, the relationship between media ownership structure and publishing policies was tried to be determined in this sense. Turkey's President Recep Tayyip Erdogan, has used the metaphor Mankurt for the first time on September 20, 2015. After this date, the Turkish media showed great interest in the Mankurt metaphor. Metaphor has been used as a direct title by many newspapers. In political discourse, discourse is a matter of language. This action gains importance depending on who is said, how it is said and what effect it has. In this context, the use of the Mankurt expression as a metaphor by the President and criticism of some betrayal groups with this expression have been effective in the society. The reflections of this public impact on the national press were analyzed. In this study, it is seen that the frequency of President Erdoğan's use of Mankurt expression increases every year. On the other hand, it is concluded that the interest of the Turkish media in using this metaphor has been decreasing with each passing year. In this study, it was determined that the media that uses the Mankurt metaphor more frequently in the news content are newspapers close to the Ak Parti government. The reason for this close interest or indifference; It has been determined that the property structure of the newspapers is due to the priorities of the threshold protections that determine the ideological approaches and the agenda. In the study, a three-year content analysis of the news reflected on the first page of national newspapers was made. The concept of Mankurt appeared on the first page of Turkish national newspapers in 52 different times, 12 different dates and 3 different years. Mankurt metaphor, published 52 times on the first page of various national newspapers in three years, met more than 5 and a half million readers. Of course, if a newspaper is multiplied by the number of readings read by more than one person, it can be said that this number can double or triple. The interesting part of the study is that some newspapers insist on not using the Mankurt metaphor used by Erdoğan, but in some newspapers special attention is given to emphasizing the metaphor. While the FETO media and left opposition newspapers that Erdogan defined with the Mankurt metaphor refused to use this concept, Islamist/nationalist opposition newspapers did not mention this metaphor. However, newspapers close to government policies often used this metaphor in front page news. 